\title{
Evaluation of Dissolution Profiles of a Newly Developed Solid Oral Immediate-Release Formula Containing Alpha-Lipoic Acid
}

\author{
Anca Lucia Pop ${ }^{1}$, Simona Crișan ${ }^{2}$, Maria Bârcă ${ }^{1}$, Anne-Marie Ciobanu ${ }^{1}$, Valentin Nicolae Varlas ${ }^{3, *}$, \\ Coriolan Pop ${ }^{2}$, Mariana-Ana Pali ${ }^{2}$, Dumitru Cauni ${ }^{2}$, Emma Adriana Ozon ${ }^{1, *}$, Denisa Udeanu ${ }^{1}$ (D), \\ Simona Trifu ${ }^{4}$ and Bogdana Adriana Năsui ${ }^{5}$
}

check for updates

Citation: Pop, A.L.; Crișan, S.; Bârcă, M.; Ciobanu, A.-M.; Varlas, V.N.; Pop, C.; Pali, M.-A.; Cauni, D.; Ozon, E.A.;

Udeanu, D.; et al. Evaluation of Dissolution Profiles of a Newly Developed Solid Oral ImmediateRelease Formula Containing Alpha-Lipoic Acid. Processes 2021, 9 , 176. https://doi.org/10.3390/ pr9010176

Received: 22 December 2020

Accepted: 15 January 2021

Published: 19 January 2021

Publisher's Note: MDPI stays neutral with regard to jurisdictional claims in published maps and institutional affiliations.

Copyright: (C) 2021 by the authors Licensee MDPI, Basel, Switzerland. This article is an open access article distributed under the terms and conditions of the Creative Commons Attribution (CC BY) license (https:// creativecommons.org/licenses/by/ $4.0 /)$
1 Faculty of Pharmacy, "Carol Davila" University of Medicine and Pharmacy, 6 Traian Vuia Street, 020945 Bucharest, Romania; ancapop@hotmail.com or anca.pop@umfcd.ro (A.L.P.); maria.barca@umfcd.ro (M.B.); anne.ciobanu@umfcd.ro (A.-M.C.); denisa.udeanu@umfcd.ro (D.U.)

2 R\&D Center, AC HELCOR, Victor Babes St., 430082 Baia Mare, Romania; simona.crisan@achelcor.ro (S.C.); coriolan.pop@achelcor.ro (C.P.); mariana.pali@achelcor.ro (M.-A.P.); dumitru.cauni@achelcor.ro (D.C.)

3 Faculty of Medicine, "Carol Davila" University of Medicine and Pharmacy, 030167 Bucharest, Romania

4 Department of Clinical Neurosciences, "Carol Davila" University of Medicine and Pharmacy, 37 Dionisie Lupu St., 020021 Bucharest, Romania; simona.trifu@umfcd.ro

5 Faculty of Medicine, "Iuliu Hațieganu" University of Medicine and Pharmacy, 6 Louis Pasteur Street, 400349 Cluj-Napoca, Romania; adriana.nasui@umfcluj.ro

* Correspondence: dr.valentinvarlas@gmail.com or varlas.valentin@umfcd.ro (V.N.V.); emma.budura@umfcd.ro (E.A.O.); Tel.: +40-72-222-9561

\begin{abstract}
Alpha-lipoic acid (ALA, thioctic acid), a naturally-occurring essential dithiol compound, has become a common ingredient in many pharmaceutical and food supplement products (FSP), used in oxidative stress-dependent pathologies; oral bioavailability of ALA is limited by pharmacokinetic particularities that reduce its therapeutic efficacy-reduced solubility, lack of gastric stability and hepatic degradation, doubled by formulation hinders. The objectives were to develop a solid oral $600 \mathrm{mg}$ ALA FSP to obtain an optimal pharmaceutical profile compared to a reference listed drug (RLD) with a similarity factor $\mathrm{f}_{2}>50$. A comparative dissolution study was performed; an HPLC method was used for ALA quantification. After planning combinatory simulations (formulation stage), two prototype formulas (\#1 and \#2) were manufactured and further optimized by adjusting ALA physical characteristics and the excipients quantities (\#3 and \#4) in order to achieve the Quality Target Product Profile. A misshapen of ALA's in vitro release was observed for \#3 Formula $\left(f_{2}=31.6\right)$; the optimal profile was obtained for Formula \#4 $\left(f_{2}=58.5\right)$. A simple quantitative formula is not enough to assure good ALA bioavailability; the formulation needs multiple compounding modulations under physicochemical compatibility algorithms, with multiple dissolution profiles testing back-ups. It is essential to ensure a formulation with an in vitro dissolution comparable with the RLD, allowing the compound to reach its target level to assure the optimum claimed antioxidant activity of ALA at the cellular level, even for food supplement formulations.
\end{abstract}

Keywords: alpha-lipoic acid; tablets; dissolution rate; formulation effect; dissolution profiles; food supplements; quality target product profile

\section{Introduction}

The lipoic acid ( $\alpha$-lipoic acid, alpha-lipoic acid, thioctic acid, ALA, LA, Synonym: $( \pm)$ 1,2-Dithiolane-3-pentanoic acid, 6,8-Dithiooctanoic acid, DL- $\alpha$-Lipoic acid, DL-6,8-Thioctic acid, Lip (S2), Thioctic acid) (CAS number: 1200-22-2) [1] is an eight-carbon organosulfur fatty acid derived from caprylic acid (octanoic acid). ALA is synthesized in trace quantities in animals, found in microorganisms, plants, and animals [2,3]; humans obtain ALA via de novo mitochondrial synthesis or from food $[4,5]$ animal-derived (red meat, liver, heart, 
and kidney) or plants (spinach, broccoli, tomatoes, Brussel's sprouts, potatoes, garden peas, and rice bran) [6,7]. ALA functions in the body, much like a B-vitamin. It is an essential cofactor in the mitochondrial aerobic metabolism and multienzyme complexes, being implied in the glucose conversion and energy production [8] and a potent antioxidant [9-11]. ALA displaying an excellent scavenging activity against the hydroxyl radical (HO·), with anti-inflammatory activity-by decreasing the tumor necrosis factor (TNF)- $\alpha$, interleukin (IL)-1 beta (IL-1 $\beta$ ), and IL-6 [12,13], performing an anti-aging activity [14] metal-chelating capacities and acting on the second messenger nuclear factor $\mathrm{kB}$ without any side effects [15]; almost meets all standards of a perfect anti-aging substance [15]. Consequently, the widespread use of ALA as a functional compound is increasing [16].

The alpha-lipoic acid is present in two forms, reduced and oxidized (DHLA); it has an intramolecular disulfide bond (at C6 and C8) in its oxidized form (Figure 1). ALA is a cofactor for several enzymes, including pyruvate dehydrogenase complex (PDH; EC) and $\alpha$-ketoglutarate dehydrogenase complex (KDH; EC), two enzymes located in mitochondria and involved in energy production [17].

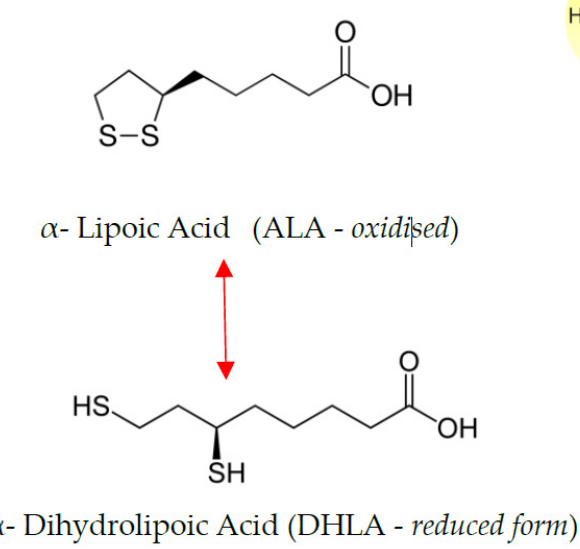

(a)

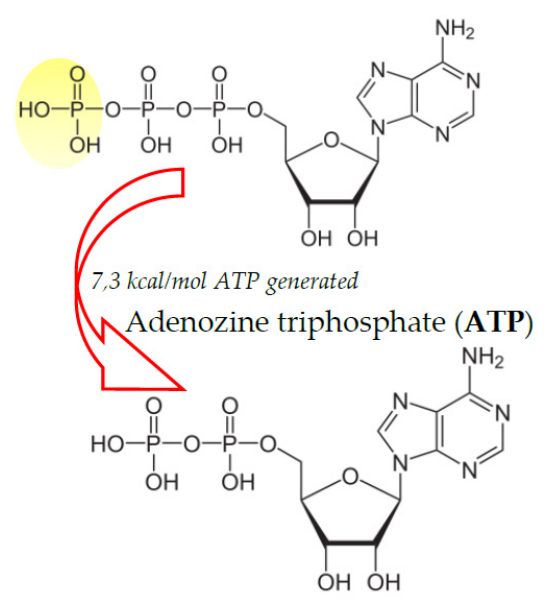

Adenozine diphosphate (ADP)

(b)

Figure 1. (a) Structure of RS $\alpha$-Lipoic acid, ( \pm )-1,2-Dithiolane-3-pentanoic acid, 6,8-Dithiooctanoic acid, DL- $\alpha$ Lipoic acid, DL-6,8-Thioctic acid, Lip(S2) (DHLA) (b) Conversion of ATP to ADP [18].

ALA has two enantiomers: R-(+)-lipoic acid (R-(+)-LA and S-(-)-lipoic acid (S-(-)LA). The naturally occurring form of ALA is the R-(+)-enantiomer, acting as an essential cofactor of the mitochondrial pyruvate dehydrogenase multienzyme complex [19,20]; due to the high electron density of 1,2-dithiolane ring, it has a high tendency for reduction of other redox-sensitive molecules [21].

ALA is hydro and lipo-soluble, being the only antioxidant to be simultaneously dissolved in the fat and water solutions [22,23]; according to the Biopharmaceutics Classification System (BCS), ALA is found in BCS II [24].

ALA is unstable under light or heat; polymerization occurs readily when the temperature is close to or higher than the melting point $\left(58.6^{\circ} \mathrm{C}\right)$; an unpleasant odor accompanies its decomposition.

After oral administration ALA passes the intestinal mucosa in a $\mathrm{pH}$-dependent manner [25] and then is transported to the intracellular compartments; further on, it is reduced to dihydrolipoic acid (DHLA) under the action of enzymes.

ALA has reduced in vivo solubility, lacks gastric stability, and underpasses hepatic degradation, generating a bioavailability of around $30 \%$ and a short half-life [26]. The absorption of ALA is reduced with meals; ALA passes the blood-brain barrier [27].

ALA is marketed as a drug but also as a food supplement. alpha-lipoic acid is present on the European medicine market under different oral formulations such as film-coated 
tablets (THIOCTACID 600 HR, Thiossen 600 mg, authorized and marketed in Romanian and Alpha Lipon Aristo ${ }^{\circledR} 600 \mathrm{mg}$ authorized and marketed in Germany), soft capsules (Alpan ${ }^{\circledR} 300 \mathrm{mg}$, alpha-RP $600 \mathrm{mg}$ and alpha-Vibolex 600 HRK-all three products being authorized and marketed in Germany) and hard capsules (alpha-MIP 200 and alpha-RP $200 \mathrm{mg}$, being marketed in Germany).

Several patents on lipoic acid were submitted during the last years, i.e., one of the first methods comprising administering an effective amount of DL-(+/-)- $\alpha$ lipoic acid, D-(+)$\alpha$-lipoic acid, and/or L-(-)- $\alpha$-lipoic acid is reduced or oxidized form or a tromethamol salt thereof, the patent expired [28]; other newer modulations on the active ingredient as alpha-lipoic acid/cyclodextrin complex [29], alpha-lipoic acid-including capsule, with a film containing a natural pigment and a caramel pigment [30], alone or in antioxidant as combinations with alpha-lipoic acid, phytoene, D-biotin, coenzyme Q10, $\alpha$ - glucosylrutin, carnitine, camosine, isoflavonoids, creatine, taurine, and $\beta$-alanine [31] and others. ALA hybrids with various activities pharmacophores possess enormous therapeutic potential but need support by reliable in vivo and clinical trials, backed up by consistent formulations to surpass the bioavailability hindrances [32].

However, as the reglementations do not compel, a series of oral ALA forms as food supplements may not fulfill the stability and bioavailability tests and standards. Formulating a stable, bioavailable oral form is a complicated task requiring a rigorous choice of excipients and controlled pharmacokinetics. A precise formulation of ALA backed by in vitro dissolution tests is essential even as a food supplement.

\subsection{Clinical Pharmacology}

ALA is a well-established treatment for neuropathic symptoms and dysfunctions in distal symmetric polyneuropathy (DSP) and type 2 diabetes [33,34].

The neuroprotective properties of ALA in diabetes are considered to result from various mechanisms, including protection against excessive oxidative stress, restoration of glutathione levels, improvement of insulin-stimulated glucose disposal, enhancement of nerve blood flow, and protection against protein glycation [35]. ALA generates an improvement in insulin sensitivity and whole-body glucose metabolism in patients with type 2 diabetes [36,37].

ALA is involved in the intracellular process of converting glucose into ATP-a form of energy that the body can use; it has antioxidant action, both in hydrophilic and hydrophobic environments, in both forms: Reduced and oxidized. ALA improves diabetes-related diseases as diabetic neuropathy (first used in Germany) and regulates the triglyceride levels in obesity.

A recent meta-analysis showed that ALA decreased leptin and increased adiponectin -duration of intervention for more than eight weeks [38]. In an in vitro model using human fetal membranes, $\alpha$-lipoic acid inhibited inflammation-induced fetal membrane weakening [39]. ALA administration may reduce inflammatory markers such as CRP, IL-6, and TNF- $\alpha$ among patients with MetS and related disorders [40].

\subsubsection{ALA in Neurological \& Psychiatric Conditions}

Recently, ALA showed slower whole brain atrophy in secondary progressive multiple sclerosis, suggesting a neuroprotective effect. Diminishing the retinal nerve fiber layer as detected by optical coherence tomography (OCT) occurs 3-6 months following acute optic neuritis (AON), indicating retinal nerve ganglion cells axonal degeneration. Simultaneously, corticosteroids speed AON recovery, neuroprotective therapies for AON are lacking [41].

LA supplementation significantly reduces TBARS, AOPP, improves TAS levels in healthy subjects, but it showed significant differences in bipolar or schizophrenic patients group [42-44] a need for well-designed clinical trials to enhance the clinical evidence of ALA effects [45]. 


\subsubsection{ALA and Cystinuria}

Cystinuria, the recurrent formation of cystine-based kidney stones, with a high frequency of recurrence, often requiring repetitive surgical interventions to remove large stones [46], is caused by mutations in the SLC3A1 and/or SLC7A9 gene(s) [47]. Lipoic acid and derivatives can prevent or slow the development of cystine kidney stones [48].

\subsubsection{ALA in PCOS}

High-mobility-group-box-1 (HMGB1) was shown to increase in polycystic ovary syndrome (PCOS) due to reduced cystic-fibrosis-transmembrane-conductance-regulator (CFTR) expression in the ovary, associated with insulin resistance and inflammation. Inositols and ALA derivatives could positively affect insulin sensitivity, reduce androgens, and improve ovulation rhythm enhancing fertility and reducing pelvic pain in endometriosis $[49,50]$. ALA supplementation has been traditionally used in pregnant women with peripheral neuropathy [51]; used for six weeks postpartum in women after primary Csection with hysterotomy closure improved the healing process and decreased the C-section scar defects [52].

\subsubsection{ALA and Cancer}

ALA reduces chemotherapy side effects having a substantial role in potentiating and synergizing the cytotoxic effect of antineoplastic agents while protecting normal body tissue, increasing patient survivability [53]. ALA's anti-proliferative effect on tumor cells is due to the increased reduction in epidermal growth factor receptor expression ErbB2 and ErbB3 [54].

Caspases are photolytic proteins that induce intrinsic and programmed cell death $[55,56]$; ALA can affect downstream targets of the photolytic protein caspases on cancer cells. i.e., on caspase- 3 in breast cancer and neuroblastoma cell lines, ALA plays a key role in increasing p27, p21, and p53 protein expressions that mediate cell cycle arrest and apoptosis by triggering caspase- 3 activity $[57,58]$. ALA down-regulates the anti-apoptotic protein Mcl-1, Bcl-xL, and the epithelial-mesenchymal transition proteins in breast cancer cells [59-61]; ALA can significantly decrease tumor size in an animal model [62].

Increased ROS production is generated in cancer cell progression by an increased cell turnover, altered metabolic activity, and malfunction of intrinsic antioxidants [63]. ALA induces autophagy via inhibition of $\mathrm{O}$ 6-methylguanine-DNA methyltransferase (MGMT) protein, which leads to apoptosis and cytotoxicity chemo-resistant colorectal cancer cells [64,65].

The antioxidant effects of ascorbic acid and liposomal ALA as an adjuvant in cancer treatment were recently re-stated [66-68] in ovarian carcinoma cells [69], human breast cells [70,71], non-small lung cancer cells [72], human colon cancer cells [73] or hepatoma cells [74].

\subsubsection{ALA and COVID19}

Serum and tissue lactate levels increase in patients with critically ill COVID-19. Since tissues' oxygenation is insufficient in patients with COVID-19, a hypoxic environment occurs $[2,16,75,76]$.

Increasing the antioxidants levels by ALA may provide an initial defensive mechanism against COVID-19 [76]. Zhang et al. [77] administered $1200 \mathrm{mg}$ ALA therapy to 17 patients with critically ill COVID-19. After 30 days of follow-up, the mortality rate was reported two-fold lower in the ALA group than in the placebo group. ALA reduces the ADAM17 activation and its effect by inhibiting NADPH oxidase activity. ALA can reduce the viral load by preventing ACE2 upregulation [78].

ALA treatment increases intracellular $\mathrm{pH}$ and AOX levels, reducing oxidative stress and preventing tissue and cell damage by decreasing lactate production. ALA may strengthen the human host defense in SARS-CoV-2 infection; used with insulin in pa- 
tients with diabetes can have a synergistic effect against SARS-CoV-2 and can play a vital role in critically ill COVID-19 patient treatment.

\subsection{Pharmacokinetics}

The lipoic acid and or lipoic acid derivatives can be administered in the "native" form or as salts, esters, amides, prodrugs, derivatives that can be prepared using standard procedures described by Advanced Organic Chemistry (2007) [79].

The lipoic acid and or lipoic acid derivative(s) are useful for parenteral administration, topical administration, oral administration, nasal administration (or otherwise inhaled), rectal administration, or local administration, by aerosol or transdermal, for prophylactic and or treatment of one or more of the pathologies (e.g., pathologies characterized by excess amyloid plaque formation and deposition or undesired amyloid or pre-amyloid processing).

Increasing bioavailability of (R)-alpha-lipoic acid boosts antioxidant activity in the treatment of neuropathic pain.

The activity of the ALA molecule is limited by two critical factors: (i) The low stability to oxidation and heat (ii) and the low solubility [80].

\subsection{Study Objectives}

We aimed to elaborate a qualitative food supplement product based on alfa lipoic acid, $600 \mathrm{mg}$ per tablet strength, with oral administration and immediate release by performing the pharmaceutical development considering technological and bioavailability aspectscompared to the reference product. Consequently, the objectives of the present study were (a) to develop a reliable oral formula of food supplement product (FSP) thioctic acid by a Quality by Design approach $(\mathrm{QbD})$ and $(\mathrm{b})$ to test the quality of the obtained product with the rigorousness of a drug product testing, in order to assure an optimal pharmaceutical profile of thioctic acid FSP compared to the reference listed drug (RLD) with a similarity factor $f_{2}$ above 50 .

\section{Materials and Methods}

\subsection{Materials:}

Characteristic of ingredients used in the studies:

1. Alpha-lipoic acid (Azienda Chimica e Farmaceutica, Italy, batch no. Q075302);

2. Alpha-lipoic acid reference listed drug (RLD-Thiossen 600 HR; Dragenopharm Apotheker Püschl GmbH, Germania; batch number 160053).

3. Sodium Carboxymethylcellulose (JRS Pharma GmbH\&co. KG, Rosenberg, Germany, batch no. 71118010031 )

4. Magnesium stearate (Mosselman s.a, Ghlin, Belgium, batch no. 414661)

5. Colloidal silicon dioxide (Wacker Chemie AG, Nünchritz, Germany, batch no. YA79686)

All the raw materials complied with the technical specifications (Supplementary Table S1).

\subsection{Methods}

\subsubsection{Methods of Tablets Preparation}

The manufacturing process of the tablets is performed in the following stages:

Weighing the ingredients used in the manufacturing process. The necessary ingredients (alpha-lipoic acid, sodium carboxymethylcellulose, magnesium stearate, and colloidal silicon dioxide) needed for the manufacturing of the tablets are weighed according to the weighing instructions, in a room with controlled air conditioning (constant temperature and humidity: $21 \pm 2{ }^{\circ} \mathrm{C}$, respectively $50 \% \pm 10 \% \mathrm{RH}$ ) and in the required amounts.

Homogenization of the ingredients, weighted at a previous stage. The ingredients are homogenized at 70 r.p.m. (homogenizer rotation speed) for $7 \mathrm{~min}$. The homogenous mixture as an intermediate is discharged into a stainless steel container. 
The physico-chemical control of the compression mixture-according to the requirements of the Technical Specification with the issuance of a Certificate of Analysis which attests the conformity of the mixture with the specification.

Compression - the ready homogenized powder is compressed into tablets on a rotary compression machine, at the following parameters: Press speed 0-100 rpm; dispenser speed 0-60 rpm.

The physico-chemical control of the tablets is performed according to the requirements of the Technical Specification with the issuance of a Certificate of Analysis, which attests the conformity of the mixture with the specification. The parameters which are checked are appearance, assay, dissolution, and average mass.

\subsubsection{Methods of Physicochemical Properties Characterization}

Average weight

The testing was done by individually weighing 30 tablets, then calculating the average mass. The tablets comply with the test if not more than one individual mass is outside the limits of $85-115 \%$ of the average mass.

Hardness

Tablet hardness was measured with VK 200 Tablet Hardness Tester. A tablet was placed in the hardness tester, and the load required to crush the tablet was registered.

Friability

The initial weight of 10 tablets is taken, and these are placed in the Vankel friablator, rotating at $25 \mathrm{rpm}$ for four minutes, then weighed again. The difference in the weight is noted and expressed as a percentage. It should be preferably below $1.0 \%$.

Quantitative Determination of ALA by HPLC Method

\section{Materials}

According to the USP edition in force requirements, the determination of lipoic alpha acid in tablets was carried out by an HPLC method $[81,82]$. The relative SD for repeated injections of the standard solution was not more than $2.0 \%$; the reagents used were: $\mathrm{Bi}$ distilled water; Acetonitrile; Potassium phosphate; Methanol; Phosphoric acid solution [83,84]. Reference substances: Alpha-lipoic acid (Azienda Chimica e Farmaceutica, Italy).

Experimental tablets

The experimental tablets' manufacture was done in the R\&D Department using the RIVA Piccola ${ }^{\circledR}$ Rotary Tablet Press, Riva ${ }^{\circledR}$ Europe, England. Four experimental formulas were manufactured (Experimental Formula \#1; Experimental Formula \#2; Experimental Formula \#3 and Experimental Formula \#4 Batch number S580317/Exp. 03.2019).

HPLC analysis

Apparatus: For the quantitative analysis of the ALA, we used a High-Performance Liquid Chromatographic system (JASCO ${ }^{\circledR}$, Tokyo, Japan) equipped with the mixt degassing system, UV detector, chromatographic column thermostat chamber, and a Kinetex ${ }^{\circledR}$ HPLC Column, C 8, $250 \times 4.6 \mathrm{~mm}, 5 \mu \mathrm{m}$ (Phenomenex, batch no. 5708-013).

Mobile phase: Methanol: 0.005 M Phosphate solution: Acetonitrile (1160:920:180), adjust the $\mathrm{pH}$ to 3.0-3.1 with the phosphoric acid solution, filter, and degas.

Dilution buffer: $0.005 \mathrm{M}$ Phosphate solution: Acetonitrile (1:1); adjust the $\mathrm{pH}$ to 3.5-3.7 with a phosphoric acid solution, filter, and degas.

Chromatographic conditions:

- Column temperature: $350^{\circ} \mathrm{C}$;

- Flow rate: $1.2 \mathrm{~mL} / \mathrm{min}$;

- UV detection at $215 \mathrm{~nm}$;

- Injection volume: $20 \mu \mathrm{L}$;

Solutions used in the determination:

Standard solution: $50.0 \mathrm{mg}$ alpha-lipoic acid is dissolved in dilution buffer, then diluted with the same solvent to $50 \mathrm{~mL}(1.0 \mathrm{mg} / \mathrm{mL}$ alpha-lipoic acid r.s.); 
Tested solution: To $52.5 \mathrm{mg}$ tablet powder corresponding to $50.0 \mathrm{mg}$ alpha-lipoic acid, $25 \mathrm{~mL}$ of dilution buffer were added and shaken for $10 \mathrm{~min}$, then diluted with the same solvent to $50 \mathrm{~mL}$. Then filter through a 0.45 um filter.

Calculations:

We calculate the amount of alpha-lipoic acid by Formula (1):

$$
(\text { ALA } / \text { tablet }(m g))=\left(A p * \mathrm{Ge}^{*} \mathrm{M}\right) /\left(\mathrm{Ae}^{*} \mathrm{Gp}\right)
$$

Ap-the area of the peak corresponding to the alpha-lipoic acid in the sample solution;

Ge-the weight of the standard, of alpha-lipoic acid w.s./r.s.., mg;

Ae-peak area corresponding to alpha-lipoic acid in the standard solution;

$\mathrm{Gp}$ - the mass of tablet powder, $\mathrm{mg}$;

$\mathrm{M}$ - the average mass of tablets, $\mathrm{mg}$.

The System Suitability

The system suitability was tested on a reference solution $(1.024 \mathrm{mg} / \mathrm{mL}$ alpha-lipoic acid, $\mathrm{n}=6$ ) by the following parameters:

- $\quad$ Retention time $(\mathrm{t})$;

- Number of theoretical plates $(\mathrm{N})$;

- $\quad$ Asymmetry factor $(\mathrm{T})$;

- $\quad$ System precision-relative standard deviation (\% RSD) $<2 \%$ (retention time, peak area).

The selectivity and specificity of the method

In order to demonstrate the selectivity and the specificity of the method, we assessed the influence of the extraction solvent (dilution mixture), the influence of the mobile phase, and the influence of excipients (placebo) in the composition of the product (Table 1) by successively injecting the following solutions into the chromatographic system:

- The placebo solution: $0.06 \mathrm{mg} / \mathrm{mL}$ excipients in the dilution mixture;

- The pure Alpha-lipoic acid solution: $1.024 \mathrm{mg} / \mathrm{mL}$ alpha-lipoic acid in the dilution mixture;

- The reconstituted $600 \mathrm{mg}$ ALA sample solution: $1.016 \mathrm{mg} / \mathrm{mL}$ alpha-lipoic acid and $0.058 \mathrm{mg} / \mathrm{mL}$ excipients in the dilution mixture;

- $\quad$ The test formula $600 \mathrm{mg}$ sample solution-tablet, batch number S580317

Table 1. Placebo formula composition (containing excipients).

\begin{tabular}{cc}
\hline Raw Materials & $\begin{array}{c}\text { Quantity, mg/tb. } \\
\mathbf{6 0 0} \mathbf{~ m g}\end{array}$ \\
\hline Sodium carboxymethylcellulose & 22.8 \\
Magnesium stearate & 6.0 \\
Colloidal silicon dioxide & 1.2 \\
Total & 30.0 \\
\hline
\end{tabular}

\subsubsection{In Vitro Dissolution Test of Alpha-Lipoic Acid in the Final Dosage Forms}

In a Biopharmaceutics Classification System (BCS), orally administered drugs are categorized into four classes depending on the solubility and permeability. BCS class I drugs exhibit high solubility and high permeability, class II drugs low solubility and high permeability, class III drugs high solubility and low permeability, and class IV drugs low solubility and low permeability [85,86]. ALA is found in BSC II [25] and tested according to the USP ALA tablets Monograph.

The dissolution test for alpha-lipoic acid tablets was performed under the following conditions:

- Dissolution apparatus no. 2 USP (paddle);

- Dissolution medium: Water; 
- Average dissolution volume: $900 \mathrm{~mL}$;

- Rotational speed: $75 \mathrm{rpm}$;

- $\quad$ Temperature: $37 \pm 0.5^{\circ} \mathrm{C}$;

- Dissolution time: $60 \mathrm{~min}$.

\subsection{Statistics}

Statistical analysis was performed using Microsoft Excel ${ }^{\circledR} 2013$ Data Analysis software (Microsoft ${ }^{\circledR}$ Corporation, Redmond, WA, USA). We described the continuous variables using the median (range), mean and standard deviation with a $95 \% \mathrm{CI}$ or count.

The dissolution testing of immediate-release solid oral dosage forms used the FDA recommended the similarity factor $f_{2}$, which define the distance between the dissolution curves for two products, reference, and test [87]:

$$
f_{2}=50 \log \left\{\left[1+\frac{\sum_{i=1}^{P}\left(\mu_{r i}-\mu_{t i}\right)^{2}}{P}\right]^{-1 / 2} * 100\right\} .
$$

$-\mu_{r i}$ and $\mu_{i t}$ are means of the population of results at time $t_{i}$ for the reference and tested products and $\mathrm{P}$ the size of the population, by the estimator:

$$
\hat{f}_{2}=50 \log \left\{\left[1+\frac{\sum_{i=1}^{P}\left(\bar{x}_{r i}-\bar{x}_{t i}\right)^{2}}{P}\right]^{-1 / 2} * 100\right\} .
$$
at time $t_{i}$.

$-x_{r i}$ and $x_{t i}$ the experimentally observed means for the reference and tested products

\section{Results}

To develop a solid oral form of $600 \mathrm{mg}$ alpha-lipoic acid tablets, immediate-release, we have done the formula design, the Quality Target Product Profile, and subsequently tested the in vitro dissolution profiles of the selected formulas in comparison to the reference product in order to obtain a suitable, industrially scalable formula.

\subsection{Preformulation Studies}

Physico-Chemical Characterization

During the preformulation study, the reference listed drug (RLD) tablet's physicochemical characterization was done, and it is summarized in Table 2.

Table 2. Physicochemical characterization of the reference listed drug (RLD) tablet (alpha-lipoic acid (ALA) $600 \mathrm{mg}$ ).

\begin{tabular}{cc}
\hline Characteristic & Result \\
\hline Strength/dose $(\mathrm{mg})$ & 600 \\
Average weight $(\mathrm{mg})$ & 826.30 \\
Coating & Film-coated tablets \\
oblong $(19 / 9 / 6)$ \\
Diameter (lenght/width/height) $(\mathrm{mm})$ & 116 \\
Hardness $(\mathrm{N})$ & $0.17 \%$ \\
Friability & 102.79 \\
Assay (\% $w / w$ of label claim) &
\end{tabular}


Based on the characterization of the RLD, the Quality Target Product Profile (QTPP) was elaborated, and also the criteria for the product quality, safety, and efficacy of the targeted formulation were designed (Tables 3 and 4).

Table 3. Quality Target Product Profile (QTPP), designed criteria for the product, quality, safety, and efficacy of a specific product for the patient.

\begin{tabular}{cc}
\hline QTPP & Target Parameters \\
\hline Dosage form & Tablet, oblong, median line \\
Dosage design & Immediate release tablet no coating/film \\
Route of administration & Oral \\
Dosage strength & $600 \mathrm{mg}$ \\
Pharmacokinetics & Immediate release enabling T $\max$ in two hours or less; \\
Stability & bioequivalent to RLD \\
& At least 24-month shelf-life at room temperature \\
\hline
\end{tabular}

Table 4. Drug product quality attributes according to QbD plan.

\begin{tabular}{|c|c|c|c|c|c|}
\hline QTPP & Target & neters & Limits/Stipulations & $\begin{array}{c}\text { Formula \#3 } \\
\text { (600 mg ALA) }\end{array}$ & $\begin{array}{c}\text { Formula \#4 } \\
\text { (600 mg ALA) }\end{array}$ \\
\hline \multirow{14}{*}{$\begin{array}{c}\text { Drug product } \\
\text { quality attributes }\end{array}$} & \multirow[t]{4}{*}{ Physical parameters } & Appearance & $\begin{array}{l}\text { Yellow, oblong tablets, } \\
\text { uniform in appearance, } \\
\text { compact structure, } \\
\text { intact edges }\end{array}$ & Conform & Conform \\
\hline & & Odor & Characteristic & No unpleasant odor & No unpleasant odor \\
\hline & & Friability, \% & NMT 1.0 & 0.12 & 0.15 \\
\hline & & Hardness, N & NLT 100 & 159 & 176 \\
\hline & \multicolumn{2}{|c|}{ Identification } & $\begin{array}{l}\text { The retention time of } \\
\text { alpha-lipoic acid is similar to } \\
\text { that of the main peak in the } \\
\text { standard solution }\end{array}$ & Conform & Conform \\
\hline & \multirow{6}{*}{\multicolumn{2}{|c|}{$\begin{array}{c}\text { Assay } \\
\text { - ALA (mg/tablet) } \\
\text { Uniformity of dosage units } \\
\text { Dissolution, \% } \\
\text { Degradation by-products } \\
\text { Residual solvents } \\
\text { Water Content, } \%\end{array}$}} & $600 \mathrm{mg} \pm 5 \%$ & 602.80 & 612.20 \\
\hline & & & NMT 15 & 2.89 & 3.65 \\
\hline & & & RLD: 77.0 & 55.9 & 67.2 \\
\hline & & & Not applicable & Not applicable & Not applicable \\
\hline & & & Not applicable & Not applicable & Not applicable \\
\hline & & & NMT 10 & 2.01 & 2.04 \\
\hline & \multirow{3}{*}{ Microbial limits } & $\begin{array}{c}\text { Total aerobic } \\
\text { microbial count }\end{array}$ & Max. 104 UFC & 0 & 0 \\
\hline & & $\begin{array}{l}\text { Total yeast and } \\
\text { molds count }\end{array}$ & Max. 102 UFC & 0 & 0 \\
\hline & & Escherichia coli/1 g & Absent & Absent & Absent \\
\hline
\end{tabular}

Tests of compatibility between the raw materials were carried out. Critical Material Attributes (CMA) were established using quality risk management. Four formulation prototypes were prepared by direct compression, and its critical process parameters were defined using the design of experiment (DOE) approach (Table 5). As the compression force was identified as a critical process parameter influencing the following critical quality attributes: Hardness and dissolution, an acceptable range for compression force-were established.

Table 5. Critical process parameters for the direct compression stage.

\begin{tabular}{|c|c|c|}
\hline $\begin{array}{l}\text { Critical Quality Attributes } \\
\text { (CQA) }\end{array}$ & $\begin{array}{l}\text { Critical Process Parameters } \\
\text { (CPP) }\end{array}$ & Risks \\
\hline $\begin{array}{c}\text { Identity } \\
\text { Assay } \\
\text { Mass uniformity } \\
\text { Friability } \\
\text { Water content }\end{array}$ & Compression speed & Low \\
\hline $\begin{array}{l}\text { Dissolution } \\
\text { Hardness }\end{array}$ & Compression force & Medium \\
\hline
\end{tabular}




\subsection{Formulation Studies. Qualitative and Quantitative Formula Design}

Alpha-lipoic acid was presented as a light yellow crystalline powder (Alpha-Lipoic Acid Powder, Fenchem Bioteck ${ }^{\circledR}$ Ltd., Nanjing, China). On a closer organoleptic examination, it was found that it has a slightly oily appearance.

After determining the type of alpha-lipoic acid used in the formulation, the appropriate excipients for developing the oral solid dosage form were chosen based on RLD labeling, literature, and reverse engineering (Table 2), according to the inactive ingredient database (IID) for FDA-approved oral solid dosage forms [88].

Carboxy-methyl-cellulose sodium or Croscarmellose Sodium (CCS) is widely used in oral pharmaceutical formulations, primarily for its viscosity-increasing propertiesadsorbent, emulsifying agent, super-disintegrant. In contact with water, it swells rapidly to about 4-8 times its original volume. As ALA is a BCS class II drug, rapid disintegration is necessary to ensure maximum bioavailability; it was used as a tablet binder at a $1-3 \%$ concentration. Grade C03 was selected.

Magnesium stearate is the most commonly used lubricant for tablets; it was added in the limits accepted by the European Pharmacopeia as a lubricant. It ensures the regular and equal filling of the compressing machine matrix, diminishing the adherence to the punch and the matrix during compression and supporting the tablet's easy discharge. Their optimal concentration is $0.5-1.0 \%$. This ratio ensures good lubrication and provides a suitable hardness, disintegration, and dissolution of the tablets.

Magnesium stearate is widely used as a pharmaceutical excipient and is generally regarded as nontoxic following oral administration [89]. Magnesium stearate grade E05 was selected of vegetable origin.

Silica colloidal anhydrous is used as a flowing agent due to the small size of its particles and greater specific surface, which improves the flowing properties of the mixture of ingredients. Its optimal concentration has proven to be $0.5 \%$. It is a strong adsorbent and displays good stabilizing properties.

We tested two initial formulas based on the alpha-lipoic acid and excipients physicochemical properties according to the design of experiments, Formula \#1 and Formula \#2 (Table 6).

Table 6. The initial experimental ALA oral tablet formulas-600 mg ALA (\#1, \#2).

\begin{tabular}{cccc}
\hline \multirow{2}{*}{ No. } & Ingredient & Formula \#1 & Formula \#2 \\
\cline { 2 - 4 } & & \multicolumn{2}{c}{ content (\%) } \\
\hline 1. & Non-granulated ALA & 97.5 & 97.5 \\
2. & Sodium carboxymethylcellulose & 1.5 & 1.0 \\
4. & Magnesium stearate & 0.5 & 1.0 \\
5. & Colloidal silicon dioxide & 0.5 & 0.5 \\
\hline
\end{tabular}

The filling of the matrix was defective, the compression mixture stuck to the punches, the tablets' appearance was not compliant (Figure 2), and the uniformity of the finished product's mass varied above the accepted limit of 5\% (Experimental formula \#1 and \#2).

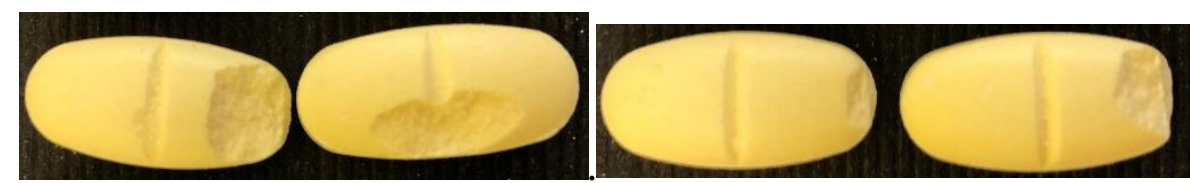

(a. Formula \#1)

(b. Formula \#2)

Figure 2. Non-compliant tablets (Experimental formula (a) \#1 and (b) \#2).

From the technological processing point of view, the ALA powder had inappropriate rheological properties due to the fluffy consistency (bulk density: $0.354 \mathrm{~g} / \mathrm{mL}$ ), so it was not suitable for compression (Figure $3 \mathrm{a}$ ). The first and second formulas were excluded 
because they were inappropriate due to high adhesion (stickiness). Thus, another type of alpha-lipoic acid was used, namely the granular one (Alpha-Lipoic Acid Powder, Fenchem Bioteck ${ }^{\circledR}$ Ltd., China) (Figure 3b).

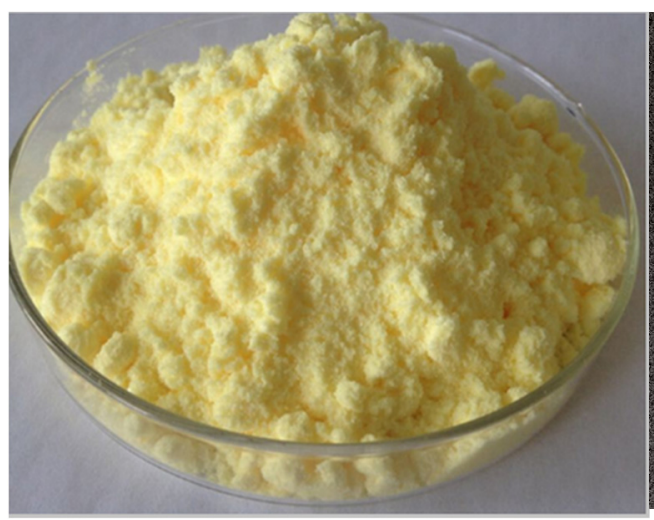

(a)

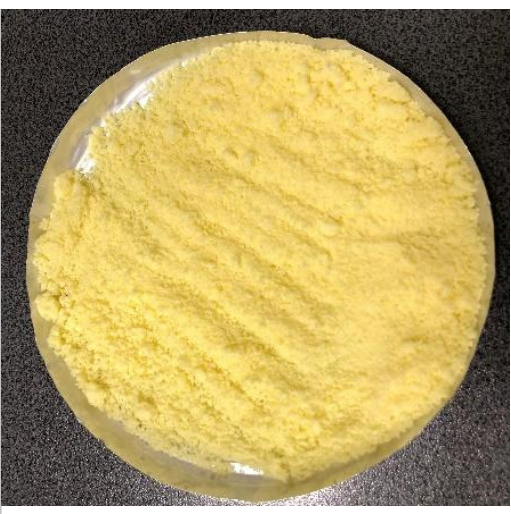

(b)

Figure 3. (a) Non-granulated alpha-lipoic acid active ingredient (b) granulated alpha-lipoic acid active ingredient.

It no longer had an oily powder's appearance, had a good flow (bulk density: $0.540 \mathrm{~g} / \mathrm{mL}$ ), the behavior towards the matrix and punches was improved (the tablets did not stick), not influencing the finished product's dissolution profile (Experimental formula \#3 and \#4) (Table 7).

Table 7. Comparison between the initial experimental ALA oral tablet formulas-600 mg ALA (\#1, \#2) and the adjusted ones (\#3, \#4).

\begin{tabular}{|c|c|c|c|c|c|c|}
\hline \multirow{2}{*}{ No. } & \multicolumn{2}{|c|}{ Ingredient } & Formula \#1 & Formula \#2 & Formula \#3 & Formula \#4 \\
\hline & & & \multicolumn{4}{|c|}{ Content (\%) } \\
\hline \multirow{2}{*}{1.} & \multirow{2}{*}{ ALA } & non-granulated & 97.5 & 97.5 & - & - \\
\hline & & granulated & - & - & 97.5 & 95.5 \\
\hline 2. & \multicolumn{2}{|c|}{ Magnesium stearate } & 0.5 & 1.0 & - & - \\
\hline 3. & \multicolumn{2}{|c|}{ Sodium Stearyl fumarate } & - & - & 0.5 & 1.0 \\
\hline 4. & \multicolumn{2}{|c|}{ Sodium Carboxymethylcellulose } & 1.5 & 1.0 & 1.5 & 3.0 \\
\hline 5. & \multicolumn{2}{|c|}{ Colloidal silicon dioxide } & 0.5 & 0.5 & 0.5 & 0.5 \\
\hline
\end{tabular}

The tablets obtained with Formula \#3 had an improved appearance compared to the previous formulations, but again, after $20 \mathrm{~min}$ following the compression, the glue appeared on the back of the experimental Formula \#3 tablet (Figure 4).

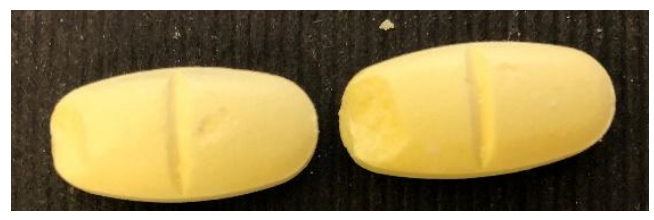

Figure 4. Experimental formula \#3-Non-compliant tablets-glue appeared on the backward after $20 \mathrm{~min}$ following the compression.

\subsubsection{Dissolution Profiles}

Dissolution Profile of the Reference Listed Drug (RLD $600 \mathrm{mg}$ )

Drug release is usually the rate-limiting process for absorption of a Biopharmaceutics Classification System (BCS) Class II compound like alpha lipoic acid due to its low solubility. Therefore, the dissolution of the RLD tablets was thoroughly evaluated. We tested the dissolution profile of the reference listed drug (Table 8, Figure 5). 
Table 8. RLD dissolution profile in $900 \mathrm{~mL}$ dissolution medium using USP apparatus two at $75 \mathrm{rpm}$.

\begin{tabular}{|c|c|c|c|c|c|c|c|c|c|c|c|c|c|c|}
\hline \multirow{2}{*}{$\begin{array}{l}\text { Time } \\
\text { (Min) }\end{array}$} & \multicolumn{14}{|c|}{ Reference Product Tablets/Percentage of Released ALA (\%) } \\
\hline & 1 & 2 & 3 & 4 & 5 & 6 & 7 & 8 & 9 & 10 & 11 & 12 & $X^{*}$ & $\pm \mathbf{S D} * *$ \\
\hline $5^{\prime}$ & 26.7 & 27.7 & 29.9 & 28.0 & 27.9 & 31.0 & 26.9 & 27.7 & 29.7 & 27.8 & 27.8 & 30.4 & 28.5 & 1.4 \\
\hline $10^{\prime}$ & 39.3 & 41.0 & 41.7 & 43.4 & 40.3 & 40.8 & 38.7 & 40.5 & 41.4 & 42.9 & 40.4 & 40.4 & 40.9 & 1.3 \\
\hline $15^{\prime}$ & 47.5 & 48.6 & 50.3 & 51.6 & 49.2 & 52.5 & 47.3 & 48.7 & 49.9 & 51.4 & 49.1 & 52.1 & 49.9 & 1.7 \\
\hline $30^{\prime}$ & 61.9 & 62.6 & 63.9 & 66.3 & 63.1 & 65.6 & 61.2 & 62.5 & 63.8 & 66.2 & 63.0 & 65.2 & 63.8 & 1.7 \\
\hline $45^{\prime}$ & 70.3 & 70.7 & 71.4 & 75.2 & 71.0 & 72.5 & 69.4 & 70.6 & 71.3 & 74.9 & 71.1 & 72.7 & 71.8 & 1.8 \\
\hline $60^{\prime}$ & 75.7 & 76.6 & 77.2 & 78.6 & 76.0 & 77.5 & 75.7 & 76.9 & 77.1 & 78.5 & 75.8 & 77.9 & 77.0 & 1.0 \\
\hline
\end{tabular}

${ }^{*} \mathrm{X}$-average, ${ }^{* *} \mathrm{SD}$-standard deviation.

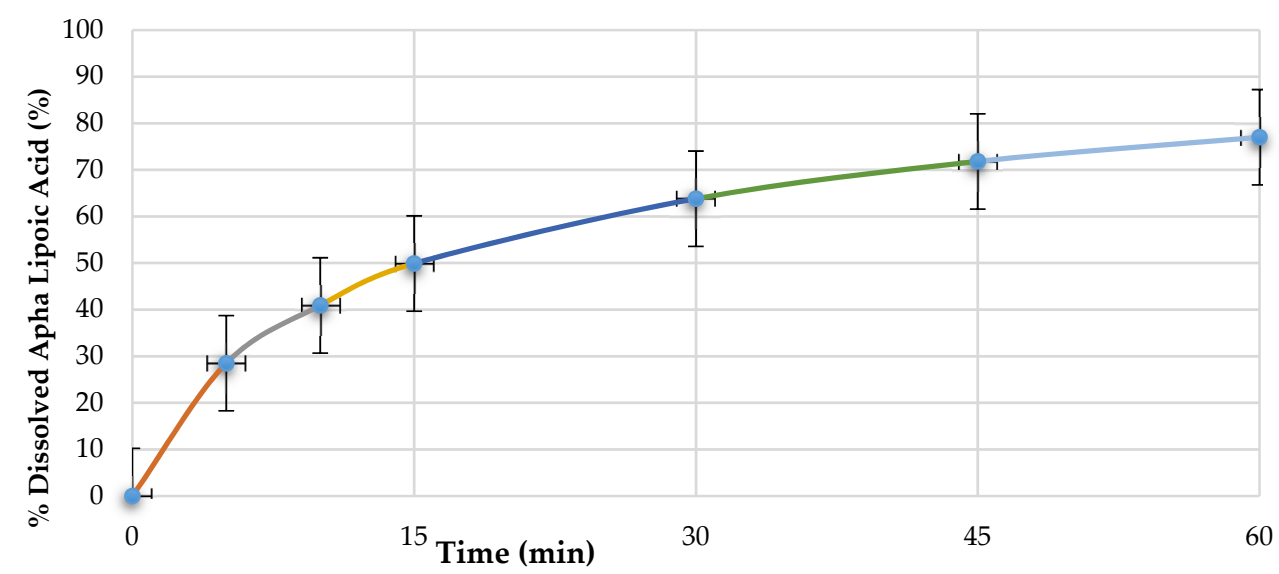

Figure 5. Reference listed formula initial dissolution profile (RLD Thiossen ${ }^{\circledR} 600 \mathrm{mg}$ ALA).

Comparative Dissolution Profile of the Selected Formula \#3 to RLD

We tested the dissolution profile on \#3 Formula and calculated the similarity factor $\left(\mathrm{f}_{2}\right)$ compared to the reference listed product dissolution profile (Thiossen ${ }^{\circledR} 600 \mathrm{mg}$, Germany) (Table 9 and Figure 6).

Table 9. The dissolution profile of the Initial Formula \#3-600 mg ALA in $900 \mathrm{~mL}$ of a medium using USP apparatus 2 at $75 \mathrm{rpm}$.

\begin{tabular}{|c|c|c|c|c|c|c|c|c|c|c|c|c|c|c|}
\hline \multirow{2}{*}{$\begin{array}{l}\text { Time } \\
\text { (Min) }\end{array}$} & \multicolumn{14}{|c|}{ Tested Tablets (n) and the Amount of ALA Released in Time (\%) } \\
\hline & 1 & 2 & 3 & 4 & 5 & 6 & 7 & 8 & 9 & 10 & 11 & 12 & $X^{*}$ & SD * \\
\hline $5^{\prime}$ & 12.1 & 12.9 & 10.7 & 13.4 & 17.0 & 14.5 & 11.9 & 12.9 & 10.5 & 13.6 & 17.0 & 14.5 & 13.4 & 2.1 \\
\hline $10^{\prime}$ & 15.8 & 17.9 & 15.7 & 17.6 & 20.4 & 19.8 & 15.8 & 18.0 & 15.7 & 17.9 & 20.6 & 19.6 & 17.9 & 1.9 \\
\hline $15^{\prime}$ & 20.7 & 23.4 & 21.3 & 22.7 & 25.6 & 23.5 & 20.8 & 23.4 & 21.5 & 22.6 & 25.5 & 23.5 & 22.9 & 1.6 \\
\hline $30^{\prime}$ & 32.5 & 38.4 & 34.8 & 35.4 & 37.6 & 38.9 & 32.6 & 38.4 & 34.9 & 35.5 & 37.4 & 39.0 & 36.3 & 2.3 \\
\hline $45^{\prime}$ & 45.2 & 49.4 & 46.5 & 46.9 & 48.1 & 51.0 & 45.6 & 49.5 & 46.6 & 46.6 & 48.1 & 51.2 & 47.9 & 2.0 \\
\hline $60^{\prime}$ & 53.7 & 57.4 & 54.9 & 56.0 & 56.2 & 57.5 & 53.6 & 56.7 & 55.0 & 56.0 & 56.1 & 57.5 & 55.9 & 1.3 \\
\hline
\end{tabular}




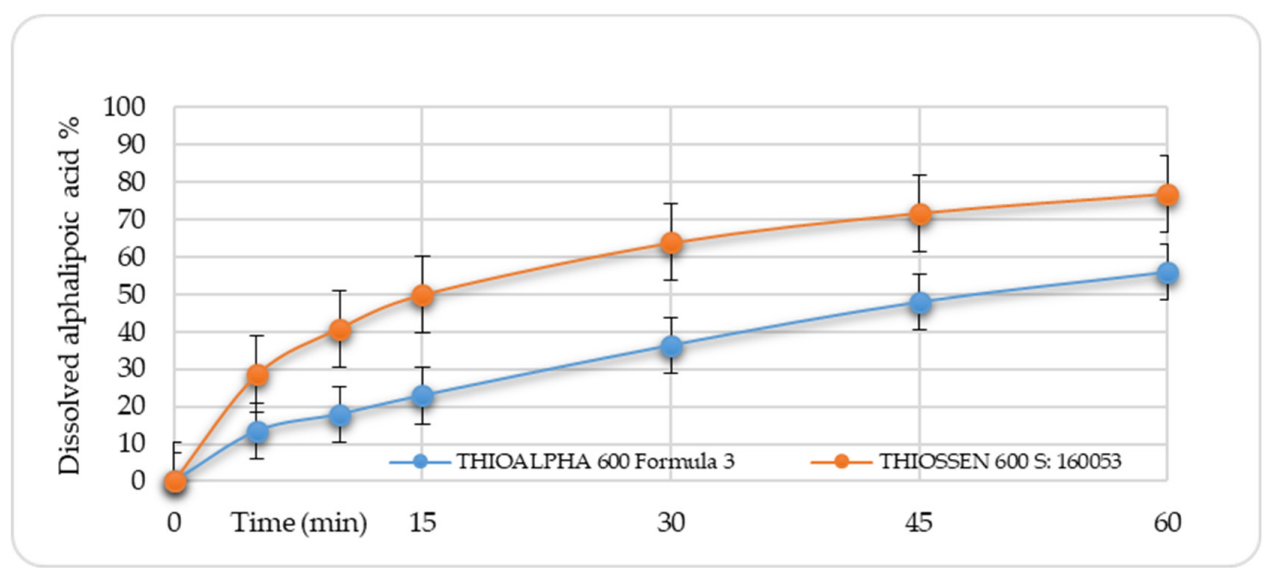

Figure 6. Comparative profile Test Formula \#3 (Thioalpha $600 \mathrm{mg}$ ALA)-Reference listed Formula (Thiossen ${ }^{\circledR} 600$ mg ALA).

Dissolution Profile of Test Formula \#4

To improve the technological compliance, dissolution profile, and similarity factor, we increased sodium stearyl fumarate and croscarmellose sodium content and developed formula \#4 (Table 2).

We tested the dissolution profile on \#4 Formula and calculated the similarity factor $\left(f_{2}\right)$ compared to the reference listed product dissolution profile (Thiossen ${ }^{\circledR} 600 \mathrm{mg}$, Germany) (Table 10 and Figure 7).

Table 10. Dissolution profile Test Formula \#4-600 mg in $900 \mathrm{~mL}$ of medium (pH as shown) using USP apparatus 2 at $75 \mathrm{rpm}$.

\begin{tabular}{|c|c|c|c|c|c|c|c|c|c|c|c|c|c|c|}
\hline \multirow{2}{*}{$\begin{array}{l}\text { Time } \\
\text { (Min) }\end{array}$} & \multicolumn{12}{|c|}{ Test Product Tablets/Percentage of Released ALA (\%) } & \multirow[b]{2}{*}{$X^{*}$} & \multirow[b]{2}{*}{$\mathrm{SD}^{*}$} \\
\hline & 1 & 2 & 3 & 4 & 5 & 6 & 7 & 8 & 9 & 10 & 11 & 12 & & \\
\hline $5^{\prime}$ & 21.7 & 23.2 & 22.3 & 22.9 & 25.6 & 23.5 & 22.2 & 23.4 & 22.5 & 22.6 & 26.0 & 23.5 & 23.3 & 1.2 \\
\hline $10^{\prime}$ & 31.9 & 37.9 & 34.7 & 35.5 & 36.8 & 39.0 & 31.9 & 38.4 & 34.5 & 35.5 & 38.0 & 38.9 & 36.1 & 1.5 \\
\hline $15^{\prime}$ & 45.3 & 48.4 & 46.7 & 47.2 & 48.1 & 51.1 & 46.2 & 50.2 & 46.8 & 46.9 & 49.0 & 51.2 & 48.1 & 1.1 \\
\hline $30^{\prime}$ & 53.8 & 57.5 & 55.9 & 56.9 & 57.2 & 58.2 & 55.6 & 57.3 & 56.5 & 56.1 & 56.5 & 60.1 & 56.8 & 1.4 \\
\hline $45^{\prime}$ & 65.2 & 69.4 & 66.5 & 66.1 & 58.1 & 61.9 & 64.6 & 59.5 & 66.6 & 62.6 & 58.1 & 61.2 & 63.3 & 1.4 \\
\hline $60^{\prime}$ & 69.7 & 71.4 & 70.9 & 72.1 & 61.2 & 67.5 & 69.6 & 62.7 & 72.0 & 63.8 & 62.1 & 63.5 & 67.2 & 1.3 \\
\hline
\end{tabular}

${ }^{*} \mathrm{X}$-average, SD—standard deviation.

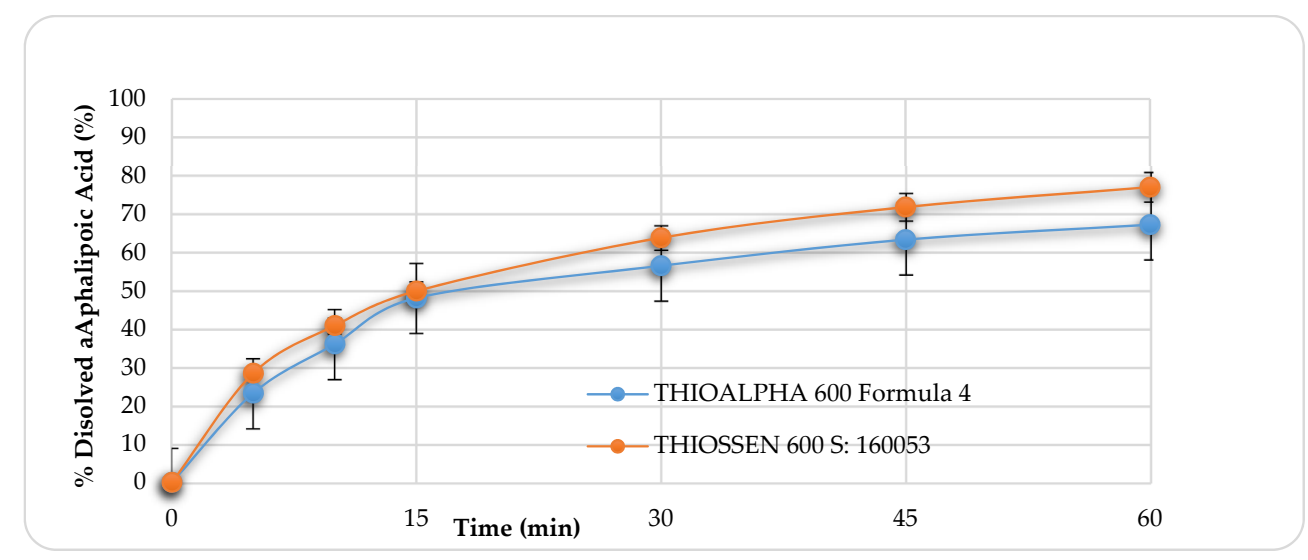

Figure 7. Comparative profile Test formula \#4 (600 mg ALA)-blue versus Reference Listed Drug (600 mg ALA)-orange. 
3.2.2. Quality Profile of the Tested Formula \#3, \#4 vs. RLD

The two formulations (Test \#3, Test \#4, and RLD) were subjected to quality and quantity control, evaluating the pharmaco-technical properties (Table 11).

Table 11. Quality parameters of the tested formula \#3, \#4 (600 mg), and Reference Product (600 mg).

\begin{tabular}{|c|c|c|c|c|}
\hline Product & $\begin{array}{c}\text { Average Tablet } \\
\text { Mass (mg) } \\
\text { SD }( \pm \%)\end{array}$ & $\begin{array}{c}\text { Hardness } \\
\text { (N) } \\
\text { NLT } 100\end{array}$ & $\begin{array}{c}\text { Friability } \\
(\%) \\
\text { NMT } 1 \\
\end{array}$ & $\begin{array}{c}\text { Concentration of Alpha-Lipoic } \\
\text { Acid (mg/tablet) }\end{array}$ \\
\hline $\begin{array}{l}\text { Test Formula \#3 } 600 \mathrm{mg} \\
\text { S570317/Exp. } 03.2019\end{array}$ & $\begin{array}{c}623.90 \\
-1.1 /+1.14\end{array}$ & 159 & 0.12 & 602.80 \\
\hline $\begin{array}{l}\text { Test Formula \#4 } 600 \mathrm{mg} \\
\text { S580317/Exp. } 03.2019\end{array}$ & $\begin{array}{c}623.4 \\
-1.42 /+1.24\end{array}$ & 176 & 0.15 & 612.20 \\
\hline $\begin{array}{l}\text { Reference Product } 600 \mathrm{mg} \\
\text { S: 17D029/Exp. } 03.2022\end{array}$ & $\begin{array}{c}826.3 \\
-1.03 /+0.88\end{array}$ & 116 & 0.17 & 616.74 \\
\hline
\end{tabular}

The quality of the obtained ALA FSP was found to be similar to that of the RLD by testing the following parameters: Average tablet mass, Hardness, Friability, Assay of alpha-lipoic acid (mg/tablet), and Dissolution.

\subsection{Chromatographic Analysis. Validation of the Chromatographic Method}

3.3.1. The Stability and Performance of the Chromatographic System (System Suitability)

We tested the chromatographic system's reliability by multiple injections $(n=6)$ of the standard solution-1,024 mg/mL alpha-lipoic acid in the dilution solvent (Figure 8). We evaluated the following parameters: (a) Retention time (t); (b) Number of theoretical plates (N); (c) Asymmetry factor (T); (d) System repeatability-RSD $<2 \%$ (retention time, peak area) (Table 12).

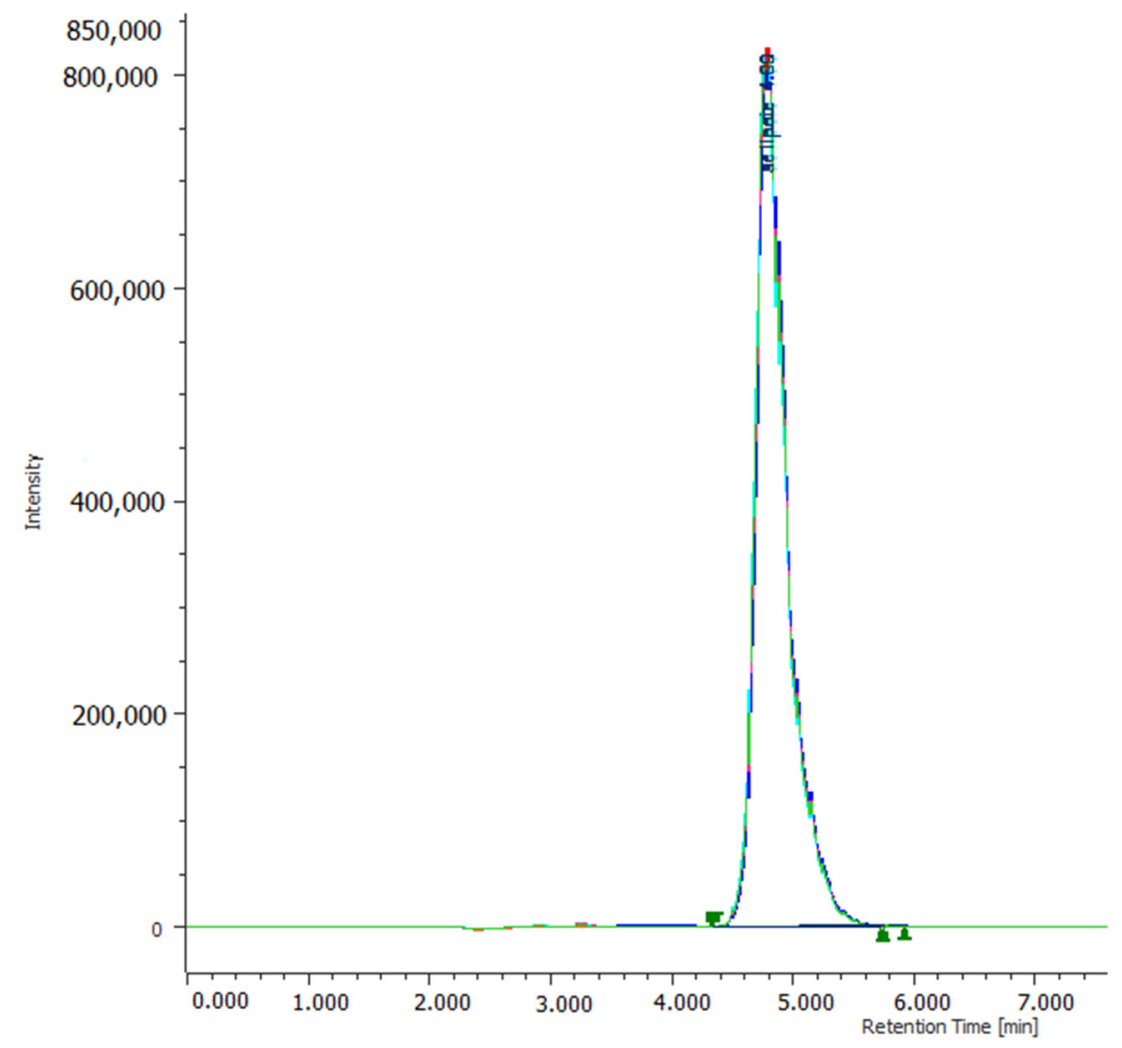

Figure 8. Testing of system suitability ( $n=6$, overlay chromatograms). 
Table 12. System performance characterization parameters (retention time, peak height, area, $\mathrm{Wh} / 2$, asymmetry factor, and theoretical plates).

\begin{tabular}{|c|c|c|c|c|c|c|}
\hline $\begin{array}{l}\text { Samples of the } \\
\text { Alpha-Lipoic Acid } \\
\text { Standard Solution }\end{array}$ & $\begin{array}{c}\mathrm{T} \\
(\mathrm{min})\end{array}$ & $\begin{array}{c}\mathbf{H} \\
(\mu \mathrm{V})\end{array}$ & $\begin{array}{c}\mathrm{A} \\
(\mu \mathrm{V} \times \mathrm{s})\end{array}$ & $\begin{array}{l}\text { Wh/2, } \\
\text { (min) }\end{array}$ & $\begin{array}{l}\text { Asymmetry } \\
\text { Factor }(\mathrm{T})\end{array}$ & $\begin{array}{c}\text { Theoretical } \\
\text { Plates (n) }\end{array}$ \\
\hline 1. & 4.90 & 810,256 & $7,899,718$ & 0.135 & 1.56 & 7333 \\
\hline 2. & 4.89 & 812,991 & $7,915,821$ & 0.135 & 1.56 & 7326 \\
\hline 3. & 4.89 & 813,739 & $7,915,642$ & 0.134 & 1.56 & 7335 \\
\hline 4. & 4.89 & 813,211 & $7,914,573$ & 0.134 & 1.56 & 7338 \\
\hline 5. & 4.89 & 814,106 & $7,913,492$ & 0.134 & 1.56 & 7334 \\
\hline 6 & 4.89 & 815,434 & $7,927,189$ & 0.134 & 1.56 & 7340 \\
\hline $\mathrm{n}$ & 6 & 6 & 6 & 6 & 6 & 6 \\
\hline$x$ & 4.89 & 813,290 & $7,914,406$ & 0.134 & 1.56 & 7334 \\
\hline SD & 0.003 & 1568,8 & 7995.1 & 0.0 & 0.002 & 4.42 \\
\hline RSD & 0.07 & 0.21 & 0.11 & 0.087 & 0.17 & 0.07 \\
\hline
\end{tabular}

$n=$ number of injections, $\mathrm{X}$-average, SD—standard deviation; RSD—relative standard deviation (\%).

\subsubsection{Selectivity and Specificity of the Method}

We tested the selectivity and specificity of the method regarding the influence of the extraction solvent, mobile phase, and excipients in the product composition (placebo, Figure 9a). As ALA retention time was 4.9 min for a standard solution (Figure 9b), for reconstituted $600 \mathrm{mg}$ ALA sample solutions (Figure 9c) and also for tested formula \#4 solution (Figure $9 \mathrm{~d}$ ) and no peak was seen in the solvent, mobile phase or placebo solution chromatograms at $4.9 \mathrm{~min}$, the selectivity of the method was demonstrated.

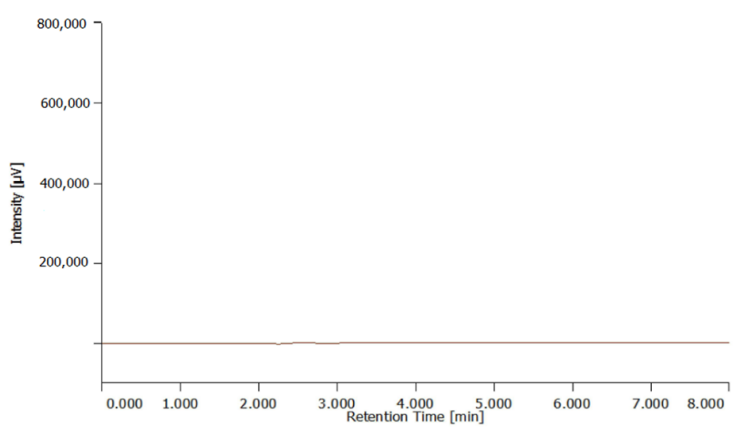

(a)

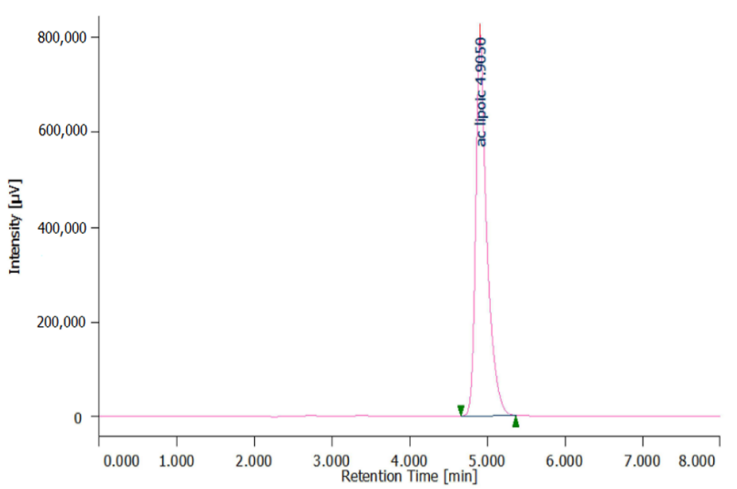

(c)

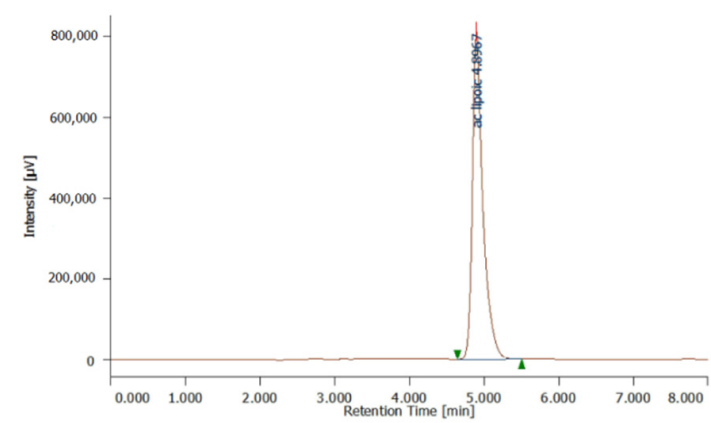

(b)

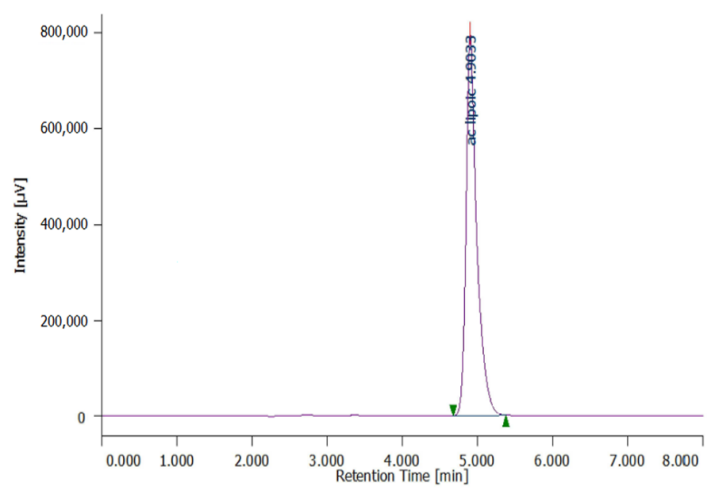

(d)

Figure 9. (a) The chromatogram of the placebo solution, (b) The chromatogram of the alpha-lipoic acid standard solution $1.024 \mathrm{mg} / \mathrm{mL}$ (c) The chromatogram of the reconstituted $600 \mathrm{mg}$ ALA sample solutions (d) The chromatogram of the tested formula \#4 solution $600 \mathrm{mg}$ - tablets (batch no. S580317). 


\section{Discussion}

The recent literature shows continuous research on improving the BCS class II ALA biodisponibility through formulation adjustments to achieve a higher bioavailability $\left(\mathrm{C}_{\max }\right.$ and AUC values) and decreased time to maximum concentration $\left(T_{\max }\right)$ and $T_{1 / 2}$. This goal is achieved by several approaches, using the natural stereoisomer R-lipoic acid (RLA) and the sodium salt (NaRLA), complexation with octenylsuccinylated high-amylose starch [90]; by encapsulation and stabilization in cyclodextrin inclusion complex [91], incorporation in natural polysaccharide-based gel beads [92], cyclodextrin inclusion complex electrospun nanofibers [93] and others; Nevertheless these forms are under development and not available in the current therapy.

Conventional release ALA racemic solid oral forms are used in therapy, both as medicines and as food supplements or vitamin mixes; the previous study showed that the standards of industrial manufactured ALA-based supplements concentration ranged from 97.8 to $104.1 \%$ and for manipulated capsules concentration ranged from 69.2 to $95.4 \%$, a great variability [90]. However, a $\mathrm{QbD}$ approach in developing the commercial forms of ALA is seldom used and can assure an optimal formulation and a biodisponibility comparable to RLD even for FSP or vitamin mixes.

Our study approaches the ALA formulation by assessing the preformulation parameters, the critical quality attributes in order to obtain a FSP with a dissolution profile similar to the reference listed drug (RLD) according to the USP.

US FDA Guidance describes the model-independent mathematical approach proposed by Moore and Flanner for calculating a similarity factor $\left(\mathrm{f}_{2}\right)$ of dissolution testing of immediate-release solid oral dosage forms describes that drug dissolution may be the rate-limiting step for drug absorption in the case of low solubility/high permeability drugs (BCS class II drugs).

We used the USP method using $900 \mathrm{~mL}$ water dissolution medium, in USP apparatus 2 , stirred one hour at $75 \mathrm{rpm}$. This method is capable of differentiating between the manufactured formulations and RLD.

The similarity factor $f_{2}$, which defines the distance between the dissolution curves for two tested products, was estimated [90]. The similarity factor $\left(f_{2}\right)$ is 100 when the difference between reference and test formulation is insignificant. Literature studies and current quality guidelines consider that a value of the $\mathrm{f}_{2}$ factor greater than 50 signifies "less than $10 \%$ difference" between profiles and is accepted as a similarity between dissolution profiles.

The similarity factor of Test Formula \#3-600 mg, and the reference product (RLD) was $\mathrm{f}_{2}=31.6$, below 50 .

The similarity factor of Test Formula \#4-600 mg, and the reference product (RLD) was $\mathrm{f}_{2}=58.5$.

The obtained $\mathrm{f}_{2}$ value of 31.6 for Test Formula \#3, compared with the reference product, is below the desired limit, so the formulation will show a weak in vivo performance, not being suitable for therapeutic use. In case of the Test Formula \#4, $\mathrm{f}_{2}$ has a value over the minimum required limit meaning the obtained tablets have a similar dissolution profile, but the value is still not close to 100, showing that the two compared products achieve different dissolution rate, which can lead to significant in vivo differences.

The parameters that define the HPLC peaks (retention time, height, area, peak width at half height) and system performance parameters (asymmetry factor, number of theoretical plates) are reproducible. The relative standard deviation was below $2 \%$ (for time retention area, peak area), demonstrating that the system is stable and efficient, corresponding to the proposed purpose (Figure 8, Table 12). Also, the chromatograms showed that placebo has no signals at the retention time of alpha-lipoic acid, so the method is selective against placebo; thus, the excipients do not interfere with the HPLC determination (Figure 9).

\section{Conclusions}

In order to develop a product based on alpha-lipoic acid, a micronutrient with several pharmacological as well as antioxidant properties, in a concentration of $600 \mathrm{mg}$ per tablet, 
with oral administration and immediate release, we have performed the pharmaceutical development taking into account technological and dissolution aspects-compared to the reference listed drug (RLD).

The present research started with the preformulation studies on the active ingredient physical properties according to the Quality Target Product Profile (QTPP) defined based on the properties of the drug substance, characterization of the RLD product, and consideration of the RLD label. Identification of critical quality attributes (CQAs) targeted the drug bioavailability not to fail the reference drug product; and included assay, mass uniformity, hardness, friability, and dissolution.

A design of experiment (DOE) was conducted to identify the critical material attributes (CMA), showing that the granular form of ALA is more suitable to be processed under solid dosage forms than the powdered one that led to sticking materials and patchy tablets.

The second design of the experiment (DOE) was conducted to identify the critical process parameters (CPP); it showed that a strong compression force could negatively impact the critical quality attributes of the formulation like hardness and dissolution; thus, an acceptable range for compression force was established.

The formulation studies led to four final powder formulas that presented a good flowability, considered adequate for the direct compression process. After the materials were compacted, we could notice that the first two formulas drove to improper nonhomogeneous tablets, being excluded from the following tests.

The other two formulations (Test \#3 and Test \#4) were subjected to quality and quantity control, evaluating the pharmaco-technical properties, dissolution rates, and assay. In terms of physical characteristics, the fourth formulation leads to good mechanical resistance, low friability, and excellent mass uniformity compared to the third formulation and comparable qualities as the reference product.

ALA is a poorly soluble, highly permeable Biopharmaceutics Classification System (BCS) Class II compound. Consequently, we focused on predicting in vivo performance using a dissolution method. The developed alpha-lipoic acid 600 formulation (Test \#4) is characterized by a dissolution rate similar to the reference product. The release is de facto a slow-release, the value obtained after $60 \mathrm{~min}$ not being a saturation value, neither in the test product nor in the reference one.

The analytical variability between the same series's tablets is low, less than $4 \%$, which proves the uniformity of dissolution rate in the same batch.

The dissolution rate for Test \#4 formulation is higher than Test \#3 formulation due to the presence of a greater amount of sodium carboxymethylcellulose used, its disintegrant properties being well known.

Also, in the release of ALA from the solid dosage forms, the direct compression method played an important role, by all its advantages, shortening the time needed for disintegration.

A simple quantitative formula is not enough to assure good ALA bioavailability; the formulation needs multiple compounding modulations under physicochemical compatibility algorithms, with multiple dissolution profiles testing back-ups. It is essential to ensure a formulation with an in vitro dissolution comparable with the RLD, allowing the compound to reach its target level to assure the optimum claimed antioxidant activity of ALA at the cellular level, even for food supplement formulations. 
Supplementary Materials: The following are available online at https:/ / www.mdpi.com/2227-971 7/9/1/176/s1, Table S1. Characteristic of ingredients used in the studies.

Author Contributions: Conceptualization, A.L.P.; Data curation, S.C., A.-M.C., M.-A.P., D.C., D.U., S.T., and B.A.N.; Formal analysis, S.C., A.-M.C., M.-A.P., and D.C.; Funding acquisition, C.P., and A.L.P.; Investigation, M.-A.P., and D.C.; Methodology, A.L.P., S.C., M.B., A.-M.C., M.-A.P., D.U., and B.A.N.; Project administration, A.L.P., S.C., and C.P.; Resources, A.L.P., S.C., and S.T.; Software, V.N.V., and D.C.; Supervision, M.B., C.P., and B.A.N.; Validation, S.C., A.-M.C., and E.A.O.; Visualization, A.-M.C., V.N.V., E.A.O., and S.T.; Writing-original draft, A.L.P., D.C., and B.A.N.; Writing-review and editing, A.L.P., A.-M.C., V.N.V., E.A.O., D.U., S.T., and B.A.N. Authors with equal contribution with the first author: S.C., A.-M.C. and S.T.; S.C., A.-M.C. and S.T. have made the equally important contribution to this paper. All authors have read and agreed to the published version of the manuscript.

Funding: This research received no external funding.

Institutional Review Board Statement: Not applicable.

Informed Consent Statement: Not applicable.

Acknowledgments: The authors extend their gratitude to AC HELCOR R\&D Center for providing reference and experimental formulation samples and different testing facilities.

Conflicts of Interest: The authors declare no conflict of interest regarding this paper's publication.

$\begin{array}{ll}\text { Abbreviations } \\ \text { ALA } & \text { Alpha-lipoic acid } \\ \text { AOX } & \text { Antioxidant } \\ \text { ADAM17 } & \text { ADAM metallopeptidase domain 17 } \\ \text { AOPP } & \text { Advanced Oxidation Protein Products } \\ \text { AON } & \text { Acute Optic Neuritis } \\ \text { BCS } & \text { Biopharmaceutics Classification System } \\ \text { Bcl-xL } & \text { B-cell lymphoma-extra large } \\ \text { CI } & \text { Confidence Interval } \\ \text { CMA } & \text { Critical Material Attributes } \\ \text { CQAs } & \text { Critical Quality Attributes } \\ \text { CCS } & \text { Croscarmellose Sodium } \\ \text { CFTR } & \text { Cystic-fibrosis-transmembrane-conductance-regulator } \\ \text { CRP } & \text { C-Reactive protein } \\ \text { DOE } & \text { Design of Experiments } \\ \text { EU } & \text { European Union } \\ \text { FDA } & \text { Food Drug Administration } \\ \text { HPLC } & \text { High-Performance Liquid Chromatography } \\ \text { HMGB1 } & \text { High-mobility-group-box-1 } \\ \text { IID } & \text { Inactive Ingredient Database } \\ \text { IL-6 } & \text { Interleukin 6 } \\ \text { FSP } & \text { Food Supplement Products } \\ \text { MetS } & \text { Metabolic Syndrome } \\ \text { Mcl-1 } & \text { Myeloid leukemia cell differentiation protein } \\ \text { MGMT } & \text { O 6-methylguanine-DNA methyltransferase } \\ \text { NSAIDs } & \text { Non-steroidal anti-inflammatory drugs } \\ \text { NADPH } & \text { Nicotinamide adenine dinucleotide } \\ \text { OCT } & \text { optical coherence tomography } \\ \text { PCOS } & \text { polycystic ovary syndrome } \\ \text { PSD } & \text { Particle Size Distributions } \\ \text { RLD } & \text { Reference Listed Drug } \\ \text { R\&D } & \text { Research and Development } \\ \text { RPM } & \text { Rotation per minute } \\ & \end{array}$




\begin{tabular}{|c|c|}
\hline RSD & Relative Standard Deviation \\
\hline QTPP & Quality Target Product Profile \\
\hline $\mathrm{QbD}$ & Quality by Design \\
\hline $\mathrm{WHO}$ & World Health Organization \\
\hline SPSS $^{\circledR}$ & Statistical Package for the Social Sciences, IBM $^{\circledR}$ \\
\hline SLCA & Solute Carrier Family Member \\
\hline TBARS & Thiobarbituric acid reactive substances \\
\hline TAS & Total Antioxidant Status \\
\hline $\mathrm{T}_{\max }$ & Time to peak plasma levels \\
\hline TNF $\alpha$ & Alpha Tumoral Necrosis Factor \\
\hline USP & United States Pharmacopoeia \\
\hline
\end{tabular}

\section{References}

1. National Center for Biotechnology Information. PubChem Compound Summary for CID 6112, Lipoic Acid. Available online: https:/ / pubchem.ncbi.nlm.nih.gov/compound/Lipoic-acid (accessed on 16 January 2021).

2. Reed, L.J. Multienzyme complexes. Accounts Chem. Res. 1974, 7, 40-46. [CrossRef]

3. Navari-Izzo, F.; Quartacci, M.F.; Sgherri, C. Lipoic acid: A unique antioxidant in the detoxification of activated oxygen species. Plant Physiol. Biochem. 2002, 40, 463-470. [CrossRef]

4. Biewenga, G.P.; Haenen, G.R.; Bast, A. The pharmacology of the antioxidant lipoic acid. Gen. Pharmacol. Vasc. Syst. 1997, 29, 315-331. [CrossRef]

5. Bilska, A.; Wlodek, L. Lipoic acid-The drug of the future? Pharmacol. Rep. 2005, 57, 570-577.

6. Kramer, K.; Hoppe, P.P.; Packer, L. R $\alpha$ Lipoic acid. In Nutraceuticals in Health and Disease Prevention; Dekker, M., Ed.; CRC Press: New York, NY, USA, 2001; pp. 273-275.

7. Pagano, C.; Calarco, P.; Ceccarini, M.R.; Beccari, T.; Ricci, M.; Perioli, L. Development and Characterization of New Topical Hydrogels Based on Alpha Lipoic Acid-Hydrotalcite Hybrids. Cosmetics 2019, 6, 35. [CrossRef]

8. Data, P. Alpha-lipoic acid. Arzneimittelforschung 1995, 45, 872-874.

9. Kofuji, K.; Nakamura, M.; Isobe, T.; Murata, Y.; Kawashima, S. Stabilization of $\alpha$-lipoic acid by complex formation with chitosan. Food Chem. 2008, 109, 167-171. [CrossRef]

10. Andreeva-Gateva, P.; Traikov, L.; Sabit, Z.; Bakalov, D.; Tafradjiiska-Hadjiolova, R. Antioxidant Effect of Alpha-Lipoic Acid in 6-Hydroxydopamine Unilateral Intrastriatal Injected Rats. Antioxidants 2020, 9, 122. [CrossRef]

11. Xiong, Y.; Yin, Q.; Li, J.; He, S. Oxidative Stress and Endoplasmic Reticulum Stress Are Involved in the Protective Effect of Alpha Lipoic Acid Against Heat Damage in Chicken Testes. Animals 2020, 10, 384. [CrossRef]

12. Li, G.; Fu, J.; Zhao, Y.; Ji, K.; Luan, T.; Zang, B. Alpha-lipoic acid exerts anti-inflammatory effects onlipopolysaccharide-stimulated rat mesangial cells via inhibition of nuclear factor kappa B (NF- $\mathrm{B}$ ) signalingpathway. Inflammation 2015, 38, 510-519. [CrossRef]

13. Moura, F.A.; De Andrade, K.Q.; Dos Santos, J.C.F.; Goulart, M.O.F. Lipoic acid: Its antioxidant and anti-inflammatory role and clinical applications. Curr. Top. Med. Chem. 2015, 15, 458-483. [CrossRef]

14. Pagano, G.; Pallardó, F.V.; Lyakhovich, A.; Tiano, L.; Fittipaldi, M.R.; Toscanesi, M.; Trifuoggi, M. Aging-Related Disorders and Mitochondrial Dysfunction: A Critical Review for Prospect Mitoprotective Strategies Based on Mitochondrial Nutrient Mixtures. Int. J. Mol. Sci. 2020, 21, 7060. [CrossRef]

15. Beitner, H. Randomized, placebo-controlled, double blind study on the clinical efficacy of a cream containing $5 \% \alpha$-lipoic acid related to photoageing of facial skin. Br. J. Dermatol. 2003, 149, 841-849. [CrossRef]

16. Takahashi, H.; Bungo, Y.; Mikuni, K. The aqueous solubility and thermal stability of $\alpha$-lipoic acid are enhanced by cyclodextrin. Biosci. Biotechnol. Biochem. 2011, 75, 633-637. [CrossRef]

17. Hiller, S.; DeKroon, R.; Xu, L.; Robinette, J.; Winnik, W.; Alzate, O.; Yi, X. $\alpha$-Lipoic acid protects mitochondrial enzymes and attenuates lipopolysaccharide-induced hypothermia in mice. Free Radic. Biol. Med. 2014, 71, 362-367. [CrossRef]

18. Wikipedia, Yikrazuul NEUROtiker, Public Domain. Available online: https:// commons.wikimedia.org/w/index.php?curid=41 76588and1397101 (accessed on 20 September 2020).

19. Biewenga, G.; Vriesmann, M.F.; Haenen, G.R.M.M.; Bast, A. The identification of a new metabolite of lipoic acid in man: 3ketolipoic acid. In Lipoic Acid-A Pharmacochemical Study; Biewenga, G., Ed.; Vrije Universiteit: Amsterdam, The Netherlands, 1997; pp. 137-152.

20. Packer, L.; Witt, E.H.; Tritschler, H.J. Alpha-Lipoic acid as a biological antioxidant. Free Radic. Biol. Med. 1995, 19, 227-250. [CrossRef]

21. Moini, H.; Packer, L.; Saris, N.-E.L. Antioxidant and prooxidant activities of $\alpha$-lipoic acid and dihydrolipoic acid. Toxicol. Appl. Pharmacol. 2002, 182, 84-90. [CrossRef]

22. Bernkop-Schnürch, A.; Schuhbauer, H.; Clausen, A.E.; Hanel, R. Development of a sustained release dosage form for alpha-lipoic acid. I. Design and in vitro evaluation. Drug Dev. Ind. Pharm. 2004, 30, 27-34. [CrossRef]

23. Ikuta, N.; Tanaka, A.; Otsubo, A.; Ogawa, N.; Yamamoto, H.; Mizukami, T.; Arai, S.; Okuno, M.; Terao, K.; Matsugo, S. Spectroscopic studies of R(+)- $\alpha$-lipoic acid—cyclodextrin complexes. Int. J. Mol. Sci. 2014, 15, 20469-20485. [CrossRef] 
24. Carbone, C.; Arena, E.; Pepe, V.; Prezzavento, O.; Cacciatore, I.; Turkez, H.; Puglisi, G. Nanoencapsulation strategies for the delivery of novel bifunctional antioxidant $/ \sigma 1$ selective ligands. Colloids Surf. B Biointerfaces 2017, 155, 238-247. [CrossRef] [PubMed]

25. Mousavi, T.; Hadizadeh, N.; Nikfar, S.; Abdollahi, M. Drug discovery strategies for modulating oxidative stress in gastrointestinal disorders. Expert Opin. Drug Discov. 2020, 15, 1309-1341. [CrossRef]

26. Brufani, M.; Figliola, R. (R)- $\alpha$-lipoic acid oral liquid formulation: Pharmacokinetic parameters and therapeutic efficacy. Acta Biomed. Atenei Parm. 2014, 85, 108-115.

27. Mahboob, A.; Farhat, S.M.; Iqbal, G.; Babar, M.M.; Zaidi, N.-U.-S.S.; Nabavi, S.M.; Ahmed, T. Alpha-lipoic acid-mediated activation of muscarinic receptors improves hippocampus-and amygdala-dependent memory. Brain Res. Bullet. 2016, 122, 19-28. [CrossRef] [PubMed]

28. Frank, C.; Hermann-August, H.; Wolfgang, G.; Heinz, U.; Meda, P. Use of DL-(+/-)- $\alpha$-Lipoic Acid, D-(+)- $\alpha$-Lipoic Acid, $\alpha$-Lipoic Acid in Reduced or Oxidized form or Salts for Treating Circulatory Disorders. Patent No. US5650429A/1997-07-22, free from 2015-11-08,

29. Helmut, R.; Mark, B.; Chemie, A.G.W. Process for Preparing an Alpha-Lipoic Acid/Cyclodextrin Complex and Product Prepared. U.S. Patent No. 8,481,716, 9 September 2013.

30. Hwan, K.C.; Park, K.S.; Yoon, H.N. Alpha Lipoic Acid Capsule Composition Stabilized in Water Phase and Method for preparing the same. U.S. Patent Application No. 12/294,858, 2010.

31. Ruppert, S. Emulsion comprising substituted saccharides Application PCT/EP2003/010817, WO/2004/030644, 2004.

32. Koufaki, M. Therapeutic applications of lipoic acid: A patent review (2011-2014). Expert Opin. Ther. Patents 2014, 24, 993-1005. [CrossRef]

33. Hermann, R.; Mungo, J.; Cnota, P.J.; Ziegler, D. Enantiomer-selective pharmacokinetics, oral bioavailability, and sex effects of various alpha-lipoic acid dosage forms. Clin. Pharmacol. Adv. Appl. 2014, 6, 195. [CrossRef]

34. Canosa, S.; Paschero, C.; Carosso, A.; Leoncini, S.; Mercaldo, N.; Gennarelli, G.; Benedetto, C.; Revelli, A. Effect of a Combination of Myo-Inositol, Alpha-Lipoic Acid, and Folic Acid on Oocyte Morphology and Embryo Morphokinetics in non-PCOS Overweight/Obese Patients Undergoing IVF: A Pilot, Prospective, Randomized Study. J. Clin. Med. 2020, 9, 2949. [CrossRef]

35. Rochette, L.; Ghibu, S.; Richard, C.; Zeller, M.; Cottin, Y.; Vergely, C. Direct and indirect antioxidant properties of $\alpha$-lipoic acid and therapeutic potential. Mol. Nutr. Food Res. 2013, 57, 114-125. [CrossRef]

36. Mohammadshahi, M.; Zakizadeh, E.; Ahmadi-Angali, K.; Ravanbakhsh, M.; Helli, B. The synergic effects of alpha-lipoic acid supplementation and electrical isotonic contraction on anthropometric measurements and the serum levels of VEGF, NO, sirtuin-1, and PGC1- $\alpha$ in obese people undergoing a weight loss diet. Arch. Physiol. Biochem. 2020, 1-7. [CrossRef]

37. Ghibu, S.; Craciun, C.E.; Rusu, R.; Morgovan, C.; Mogosan, C.; Rochette, L.; Gal, A.F.; Dronca, M. Impact of Alpha-Lipoic Acid Chronic Discontinuous Treatment in Cardiometabolic Disorders and Oxidative Stress Induced by Fructose Intake in Rats. Antioxidants 2019, 8, 636. [CrossRef]

38. Haghighatdoost, F.; Gholami, A.; Hariri, M. Alpha-lipoic acid effect on leptin and adiponectin concentrations: A systematic review and meta-analysis of randomized controlled trials. Eur. J. Clin. Pharmacol. 2020, 1-9. [CrossRef]

39. Kumar, D.; Moore, R.M.; Sharma, A.; Mercer, B.M.; Mansour, J.M.; Moore, J.J. In an in-vitro model using human fetal membranes, $\alpha$-lipoic acid inhibits inflammation induced fetal membrane weakening. Placenta 2018, 68, 9-14. [CrossRef] [PubMed]

40. Akbari, M.; Ostadmohammadi, V.; Tabrizi, R.; Mobini, M.; Lankarani, K.B.; Moosazadeh, M.; Heydari, S.T.; Chamani, M.; Kolahdooz, F.; Asemi, Z. The effects of alpha-lipoic acid supplementation on inflammatory markers among patients with metabolic syndrome and related disorders: A systematic review and meta-analysis of randomized controlled trials. Nutr. Metab. 2018, 15, 39. [CrossRef] [PubMed]

41. Falardeau, J.; Fryman, A.; Wanchu, R.; Marracci, G.H.; Mass, M.; Wooliscroft, L.; Yadav, V. Oral lipoic acid as a treatment for acute optic neuritis: A blinded, placebo controlled randomized trial. Mult. Scler. J.-Exp. Transl. Clin. 2019, 5, 2055217319850193. [CrossRef] [PubMed]

42. Brennan, B.P.; Jensen, J.E.; Hudson, J.I.; Coit, C.E.; Beaulieu, A.; Pope, H.G., Jr.; Cohen, B.M. A placebo-controlled trial of acetyl-L-carnitine and $\alpha$-lipoic acid in the treatment of bipolar depression. J. Clin. Psychopharmacol. 2013, 33, 627. [CrossRef] [PubMed]

43. Dragoi, A.M.; Radulescu, I.; Năsui, B.A.; Pop, A.L.; Varlas, V.N.; Trifu, S. Clozapine: An Updated Overview of Pharmacogenetic Biomarkers, Risks, and Safety-Particularities in the Context of COVID-19. Brain Sci. 2020, 10, 840. [CrossRef] [PubMed]

44. Salehi, B.; Yılmaz, Y.B.; Antika, G.; Tumer, T.B.; Mahomoodally, M.F.; Lobine, D.; Akram, M.; Riaz, M.; Capanoglu, E.; Sharopov, F.; et al. Insights on the Use of $\alpha$-Lipoic Acid for Therapeutic Purposes. Biomolecules 2019, 9, 356. [CrossRef]

45. De Sousa, C.N.S.; Leite, C.M.G.D.S.; Medeiros, I.D.S.; Vasconcelos, L.C.; Cabral, L.M.; Patrocínio, C.F.V.; Patrocínio, M.L.V.; Mouaffak, F.; Kebir, O.; Macedo, D.S.; et al. Alpha-lipoic acid in the treatment of psychiatric and neurological disorders: A systematic review. Metab. Brain Dis. 2019, 34, 39-52. [CrossRef]

46. Mattoo, A.; Goldfarb, D.S. Cystinuria. Semin Nephrol. 2008, 28, 181-191. [CrossRef]

47. Fernández, E.; Carrascal, M.; Rousaud, F.; Abián, J.; Zorzano, A.; Palacín, M.; Chillarón, J. rBAT-b0,+ AT heterodimer is the main apical reabsorption system for cystine in the kidney. Am. J. Physiol. Renal Physiol. 2002, 283, F540-F548. [CrossRef]

48. Wiener, S.; Chi, T.; Stoller, M.L. Alpha lipoic acid as a novel therapeutic approach to cystinuria. Expert Opin. Orphan Drugs 2018, 6, 295-300. [CrossRef] 
49. Santanam, N.; Kavtaradze, N.; Murphy, A.; Dominguez, C.; Parthasarathy, S. Antioxidant supplementation reduces endometriosisrelated pelvic pain in humans. Transl. Res. 2013, 161, 189-195. [CrossRef] [PubMed]

50. Filip, L.; Duică, F.; Prădatu, A.; Creţoiu, D.; Suciu, N.; Creţoiu, S.M.; Predescu, D.-V.; Varlas, V.N.; Voinea, S.-C. Endometriosis Associated Infertility: A Critical Review and Analysis on Etiopathogenesis and Therapeutic Approaches. Medicina 2020, 56, 460. [CrossRef] [PubMed]

51. Huijs, E.; Nap, A.W. The effects of nutrients on symptoms in women with endometriosis: A systematic review. Reprod. BioMed. Online 2020, 41, 317-328. [CrossRef] [PubMed]

52. Costantino, M.; Guaraldi, C.; Costantino, D.; De Grazia, S.; Unfer, V. Peripheral neuropathy in obstetrics: Efficacy and safety of a-lipoic acid supplementation. Eur. Rev. Med. Pharmacol. Sci. 2014, 18, 2766-2771.

53. Sammour, H.; Elkholy, A.; Rasheedy, R.; Fadel, E. The effect of alpha lipoic acid on uterine wound healing after primary cesarean section: A triple-blind placebo-controlled parallel-group randomized clinical trial. Arch. Gynecol. Obstet. 2019, 299, 665-673. [CrossRef]

54. Attia, M.; Essa, E.A.; Zaki, R.M.; Elkordy, A.A. An Overview of the Antioxidant Effects of Ascorbic Acid and Alpha Lipoic Acid (in Liposomal Forms) as Adjuvant in Cancer Treatment. Antioxidants 2020, 9, 359. [CrossRef]

55. González, M.J.; Miranda-Massari, J.R.; Mora, E.M.; Guzmán, A.; Riordan, N.H.; Riordan, H.D.; Casciari, J.J.; Jackson, J.A.; Román-Franco, A. Orthomolecular oncology review: Ascorbic acid and cancer 25 years later. Integr. Cancer Ther. 2005, 4, 32-44. [CrossRef]

56. Moon, H.S. Chemopreventive Effects of Alpha Lipoic Acid on Obesity-Related Cancers. Ann. Nutr. Metab. 2016, 68, 137-144. [CrossRef]

57. Nur, G.; Nazıroğlu, M.; Deveci, H.A. Synergic prooxidant, apoptotic and TRPV1 channel activator effects of alpha-lipoic acid and cisplatin in MCF-7 breast cancer cells. J. Recept. Signal Transduct. 2017, 37, 569-577. [CrossRef]

58. Simbula, G.; Columbano, A.; Ledda-Columbano, G.; Sanna, L.; Deidda, M.; Diana, A.; Pibiri, M. Increased ROS generation and p53 activation in $\alpha$-lipoic acid-induced apoptosis of hepatoma cells. Apoptosis 2007, 12, 113-123. [CrossRef]

59. Choi, S.Y.; Yu, J.H.; Kim, H. Mechanism of alpha-lipoic acid-induced apoptosis of lung cancer cells. Ann. N. Y. Acad. Sci. 2009, 1171, 149-155. [CrossRef]

60. Lee, H.S.; Na, M.H.; Kim, W.K. $\alpha$-Lipoic acid reduces matrix metalloproteinase activity in MDA-MB-231 human breast cancer cells. Nutr. Res. 2010, 30, 403-409. [CrossRef]

61. Kafara, P.; Icard, P.; Guillamin, M.; Schwartz, L.; Lincet, H. Lipoic acid decreases Mcl-1, Bcl-xL and up regulates Bim on ovarian carcinoma cells leading to cell death. J. Ovarian Res. 2015, 8, 1-13. [CrossRef]

62. Tripathy, J.; Chowdhury, A.R.; Prusty, M.; Muduli, K.; Priyadarshini, N.; Reddy, K.S.; Banerjee, B.; Elangovan, S. $\alpha$-Lipoic acid prevents the ionizing radiation-induced epithelial-mesenchymal transition and enhances the radiosensitivity in breast cancer cells. Eur. J. Pharmacol. 2020, 871, 172938. [CrossRef]

63. Feuerecker, B.; Pirsig, S.; Seidl, C.; Aichler, M.; Feuchtinger, A.; Bruchelt, G.; Senekowitsch-Schmidtke, R. Lipoic acid inhibits cell proliferation of tumor cells in vitro and in vivo. Cancer Biol. Ther. 2012, 13, 1425-1435. [CrossRef]

64. Yuan, X.; Zhou, Y.; Wang, W.; Li, J.; Xie, G.; Zhao, Y.; Shen, L. Activation of TLR4 signaling promotes gastric cancer progression by inducing mitochondrial ROS production. Cell Death Dis. 2013, 4, e794. [CrossRef]

65. Göder, A.; Nagel, G.; Kraus, A.; Dörsam, B.; Seiwert, N.; Kaina, B.; Fahrer, J. Lipoic acid inhibits the DNA repair protein O6methylguanine-DNA methyltransferase (MGMT) and triggers its depletion in colorectal cancer cells with concomitant autophagy induction. Carcinogenesis 2015, 36, 817-831. [CrossRef]

66. Neitzel, C.; Seiwert, N.; Göder, A.; Diehl, E.; Weber, C.; Nagel, G.; Fahrer, J. Lipoic Acid Synergizes with Antineoplastic Drugs in Colorectal Cancer by Targeting p53 for Proteasomal Degradation. Cells 2019, 8, 794. [CrossRef]

67. Peng, P.; Zhang, X.; Qi, T.; Cheng, H.; Kong, Q.; Liu, L.; Ding, Z. Alpha-lipoic acid inhibits lung cancer growth via mTOR-mediated autophagy inhibition. FEBS Open Bio. 2020, 10, 607-618.

68. Thapa, M.; Dallmann, G. Role of coenzymes in cancer metabolism. In Seminars in Cell E Developmental Biology; Academic Press: New York, NY, USA, February 2002; Volume 98, pp. 44-53.

69. Qiu, M.; Liu, J.; Su, Y.; Liu, J.; Wu, C.; Zhao, B. Aloperine Induces Apoptosis by a Reactive Oxygen Species Activation Mechanism in Human Ovarian Cancer Cells. Protein Pept. Lett. 2020, 27, 860-869. [CrossRef]

70. Na, M.H.; Seo, E.Y.; Kim, W.K. Effects of $\alpha$-lipoic acid on cell proliferation and apoptosis in MDA-MB-231 human breast cells. Nutr. Res. Pract. 2009, 3, 265. [CrossRef]

71. Guerriero, E.; Sorice, A.; Capone, F.; Napolitano, V.; Colonna, G.; Storti, G.; Castello, G.; Costantini, S.; Wang, Y.J. Vitamin C effect on mitoxantrone-induced cytotoxicity in human breast cancer cell lines. PLoS ONE 2014, 9, e115287. [CrossRef] [PubMed]

72. Michikoshi, H.; Nakamura, T.; Sakai, K.; Suzuki, Y.; Adachi, E.; Matsugo, S.; Matsumoto, K. $\alpha$-Lipoic acid-induced inhibition of proliferation and met phosphorylation in human non-small cell lung cancer cells. Cancer Lett. 2013, 335, 472-478. [CrossRef]

73. Kim, W.K.; Bang, M.H.; Kim, E.S.; Kang, N.E.; Jung, K.C.; Cho, H.J.; Park, J.H.Y. Quercetin decreases the expression of ErbB2 and ErbB3 proteins in HT-29 human colon cancer cells. J. Nutr. Biochem. 2005, 16, 155-162. [CrossRef]

74. Yoon, S.; Gianturco, S.L.; Pavlech, L.L.; Storm, K.D.; Yuen, M.; Mattingly, A.N. Alpha Lipoic Acid: Summary Report. 2020. Available online: https:/ / archive.hshsl.umaryland.edu/handle/10713/12046 (accessed on 20 February 2020).

75. Cure, E.; Cure, M.C. Angiotensin-converting enzyme inhibitors and angiotensin receptor blockers may be harmful in patients with diabetes during COVID-19 pandemic. Diabetes Metab. Syndr. 2020, 14, 349-350. [CrossRef] 
76. Zhong, M.; Sun, A.; Xiao, T.; Yao, G.; Sang, L.; Zheng, X.; Zhang, J.; Jin, X.; Xu, L.; Yang, W.; et al. A Randomized, Single-blind, Group sequential, Active-controlled Study to evaluate the clinical efficacy and safety of $\alpha$-Lipoic acid for critically ill patients with coronavirus disease 2019 (COVID-19). medRxiv 2020. [CrossRef]

77. Zhang, L.; Liu, Y. Potential interventions for novel coronavirus in China: A systematic review. J. Med. Virol. 2020, 92, 479-490. [CrossRef]

78. McCarty, M.F.; DiNicolantonio, J.J. Nutraceuticals have potential for boosting the type 1 interferon response to RNA viruses including influenza and coronavirus. Prog. Cardiovasc. Dis. 2020. [CrossRef]

79. Carey, F.A.; Sundberg, R.J. Advanced Organic Chemistry: Part A: Structure and Mechanisms; Springer Science \& Business Media: Berlin/Heidelberg, Germany, 2007.

80. Çoban, Ö.; Yıldırım, S.; Bakır, T. Alpha-Lipoic Acid and Cyanocobalamin Co-Loaded Nanoemulsions: Development, Characterization, and Evaluation of Stability. J. Pharm. Innov. 2021. [CrossRef]

81. United States Pharmacopoeia. Available online: https:/ / www.usp.org (accessed on 1 August 2020).

82. Ciobanu, A.M.; Pop, A.L.; Crişan, S.; Pali, M.; Burcea-Dragomiroiu, G.T.A.; Popa, D.E.; Bârcă, M. HPLC studies for assessing the stability of carvedilol tablets. Farmacia 2017, 65, 523-531.

83. Fantozzi, R. Acido alfa-lipoico: Quando la formulazione può fare la differenza. G. Ital. Ortop. Traumatol. 2014, 40, $296-300$.

84. Cârje, A.G.; Balint, A.; Ion, V.; Pop, A.L.; Muntean, D.-L.; Sabău, R.; Imre, S. HPLC-UV method approach for the analysis and impurity profiling of captopril. Stud. Univ. Babes-Bolyai Chem. 2019, 64, 231-242. [CrossRef]

85. Murakami, T. A minireview: Usefulness of transporter-targeted prodrugs in enhancing membrane permeability. J. Pharm. Sci. 2016, 105, 2515-2526. [CrossRef]

86. Chen, J.; Huang, G.D.; Tan, S.R.; Guo, J.; Su, Z.Q. The preparation of capsaicin-chitosan microspheres (CCMS) enteric coated tablets. Int. J. Mol. Sci. 2013, 14, 24305-24319. [CrossRef]

87. Moore, W.; Flanner, H.H. Mathematical Comparison of curves with an emphasis on in vitro dissolution profiles. Pharm. Tech. 1996, 20, 64-74.

88. FDA Inactive Ingredient Search for Approved Drug Products. Available online: https://www.accessdata.fda.gov/scripts/cder/ iig/index.cfm (accessed on 18 November 2019).

89. Carlson, D.A.; Smith, A.R.; Fischer, S.J.; Young, K.L.; Packer, L. The plasma pharmacokinetics of R-(+)-lipoic acid administered as sodium R-(+)-lipoate to healthy human subjects. Altern. Med. Rev. 2007, 12, 343.

90. Celebioglu, A.; Uyar, T. Encapsulation and Stabilization of $\alpha$-Lipoic Acid in Cyclodextrin Inclusion Complex Electrospun Nanofibers: Antioxidant and Fast-Dissolving $\alpha$-Lipoic Acid/Cyclodextrin Nanofibrous Webs. J. Agric. Food Chem. 2019, 67, 13093-13107. [CrossRef]

91. Kofuji, K.; Isobe, T.; Murata, Y. Controlled release of alpha-lipoic acid through incorporation into natural polysaccharide-based gel beads. Food Chem. 2009, 115, 483-487. [CrossRef]

92. Li, Y.X.; Kim, Y.J.; Reddy, C.K.; Lee, S.J.; Lim, S.T. Enhanced bioavailability of alpha-lipoic acid by complex formation with octenylsuccinylated high-amylose starch. Carbohydr. Polym. 2019, 219, 39-45. [CrossRef]

93. Viana, C.; Ribeiro, S.M.; Moreira, A.P.; Müller, L.S.; Motta, M.J.; Monserrat, J.M.; Bohrer, D. Quantification of Alpha Lipoic Acid in Pharmaceutical Products by HPLC with Pulsed Amperometric Detection at a Gold Electrode. Curr. Anal. Chem. 2019, 15, 694-700. [CrossRef] 